\title{
Leveraging the International Economy of Intellectual Property
}

\author{
GREGORY N. MANDEL *
}

\begin{abstract}
Most international intellectual property debates ignore the fundamental question of how to optimize the global environment for innovation, focusing instead on whether a particular policy benefits or harms a particular country. The cost of this misplaced focus is significant as states fight bitterly over how to divide fixed benefits, rather than seeking to grow social welfare through greater innovation. This missed opportunity is not a surprise, however, given the difficulty of trying to identify which intellectual property regimes will support greater innovation, a task that has proven impossible to achieve directly.
\end{abstract}

This Article introduces a new empirical methodology that leverages international trade data in an effort to identify indirectly which intellectual property regimes are more likely to provide greater incentives to innovate globally. A country's trade balance in high-innovation goods tends to dictate the country's preferences for intellectual property rights regimes. Countries that export more innovation than they consume tend to favor strong intellectual property rights regimes so as to reap the greatest rents from others, while countries that import more innovation than they produce favor weaker intellectual property laws so as to take advantage of innovation by others. Neither type of country will favor intellectual property regimes that maximize global incentives to innovate. Countries that happen to produce and consume relatively equivalent value from high-innovation goods, on the other hand, will tend to have self-interested incentives for an intellectual property system that supports the greatest innovation possible. The method developed here presents an original system to try to identify such countries, providing new information and insight into the international innovation economy and intellectual property law.

\section{TABLE OF CONTENTS}

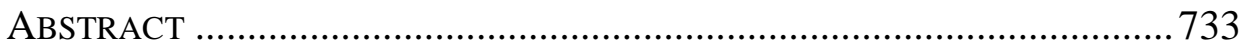

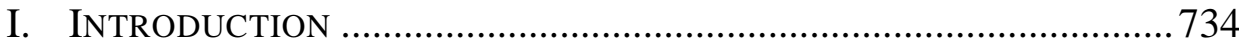

(C) 2014 Gregory N. Mandel

* Peter J. Liacouras Professor of Law \& Associate Dean for Research, Temple University-Beasley School of Law. J.D., Stanford Law School; B.A., Wesleyan University. I am grateful for valuable feedback from participants at a presentation of this work at the Institute for Prospective Technological Studies of the European Commission in April, 2014 and at the 2013 Works in Progress in Intellectual Property Conference at Seton Hall School of Law, as well as very helpful comments on earlier drafts of this article from Tom Lin, Srividhya Ragavan, and Marketa Trimble. I also want to thank Katharine Vengraitis, Marisa Johns, and Douglas Maloney for their outstanding research assistance on this project. 
II. The International Political Economy of Intellectual

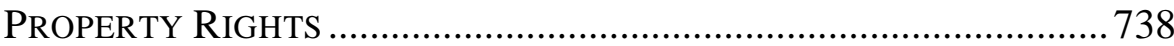

III. COUNTRIES AS INTELLECTUAL PROPERTY PROXIES ........................742

A. Patent Law Objectives ................................................................. 744

B. The Relationship Between Patent Law and Innovation ...........746

C. Conventional Approaches to Optimizing Patent Rights ..........749

D. Country Political Economy of Intellectual Property as a

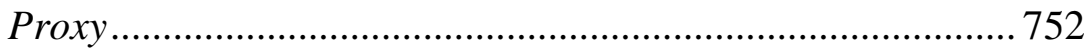

E. Country Versus Industry Proxy Signals ....................................757

IV. APPLYING INTERNATIONAL PROXY SIGNALS ....................................759

A. Measuring Intellectual Property Production and

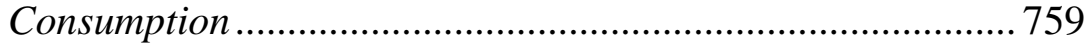

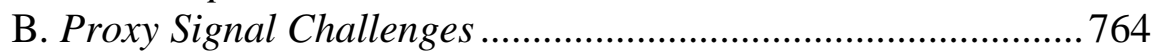

1. Dynamic Proxy Signals ........................................................ 764

2. Measuring Country Preferences .........................................766

3. Industry-Specific Patent Law ...............................................769

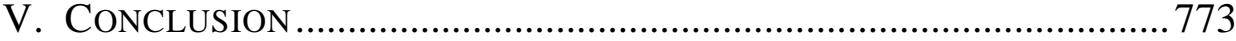

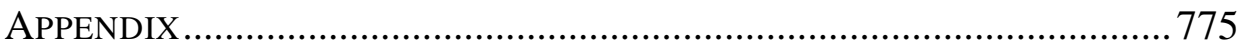

\section{INTRODUCTION}

There is a striking divergence between intellectual property law discourse at the domestic level and at the international level. Domestic intellectual property policy debates focus heavily on how to design intellectual property systems that will provide the greatest incentives to innovate. Whether an advocate is pressing for a stronger or weaker intellectual property regime, the arguments are usually framed based on which system will promote the greatest creativity, distribution, and commercialization of intellectual works.

We might expect international intellectual property debates to follow a similar course. Instead, the dialogue concerning international intellectual property policy is dominated by a tug-of-war between technologically-advanced states and developing countries over how to divide the fruits of intellectual property spoils. Rather than seeking to optimize the global environment for innovation so as to increase the size of the social welfare pie, states instead fight bitterly over how to divide the status quo. The cost of this misplaced focus on zero-sum contestations in international intellectual property debates is likely significant. This Article first explains why the political economy of international intellectual property disputes generally ignores the objective of optimizing innovation and then presents an original empirical framework that can be used to pursue a more socially constructive goal.

International intellectual property disputes, whether involving treaty negotiations, judicial proceedings, special interest advocacy, or academic discourse, primarily center on the domestic impact of particular intellectual 
property regimes for individual states and their citizens. Technologically advanced states generally press for stronger intellectual property rights, and developing countries generally try to resist such pressure in favor of weaker intellectual property regimes. ${ }^{1}$ The dominant questions tend to involve whether stronger intellectual property rights are actually in developing countries' best interests, how such countries can push back, and what trade and investment concessions resisting states can wring in exchange for agreeing to a stronger international intellectual property regime. ${ }^{2}$ The literature on these debates is

${ }^{1}$ See, e.g., Peter K. Yu, The Middle Intellectual Property Powers, in LAW AND Development of Middle-Income Countries, 84, 89-91 (Randall Peerenboom \& Tom Ginsburg eds., 2014) [hereinafter Yu, Middle Intellectual Property Powers] (discussing the rise of "middle intellectual property powers" within the traditional dispute of technologically advanced states pushing for stronger intellectual property rights regimes and developing countries pushing back); Cortney M. Arnold, Protecting Intellectual Property in Developing World: Next Stop-Thailand, 2006 DukE L. \& TECH. REV. 10, III 4-6, Mar. 27, 2006, http://scholarship.law.duke.edu/cgi/viewcontent.cgi?article $=1156 \&$ context=dltr (arguing that more developed countries press for stronger intellectual property rights in order to produce trade advantages for high-technology products, while less developed countries resist such pressure); Robert C. Bird \& Daniel R. Cahoy, The Emerging BRIC Economies: Lessons from Intellectual Property Negotiation and Enforcement, 5 Nw. J. TECH. \& INTELL. PROP. 400, 403 (2007) (examining how BRIC nations have pushed pack against what are viewed as coercive intellectual property agreements with unfavorable provisions for developing nations); Hanns Ullrich, Expansionist Intellectual Property Protection and Reductionist Competition Rules: A TRIPS Perspective, 7 J. INT'L ECON. L. 401, 401 (2004) (arguing that more developed nations favor stronger application of international intellectual property rights agreements, such as TRIPS).

In certain circumstances, for example involving intellectual property rights in genetic or cultural resources, less developed countries have sought stronger intellectual property protection. See, e.g., Srividhya Ragavan, Protection of Traditional Knowledge, 2 MinN. INTELL. PROP. REV. 1, 41-45, 51-58 (2001) (discussing a variety of efforts by indigenous peoples and less developed countries to assert intellectual property rights in traditional and cultural knowledge); Peter K. Yu, Cultural Relics, Intellectual Property, and Intangible Heritage, 81 TEMP. L. REV. 433, 437 (2008) [hereinafter Yu, Cultural Relics] (discussing less-developed countries' efforts to safeguard intangible cultural heritage through intellectual property rights).

${ }^{2}$ See, e.g., Carsten Fink \& Patrick Reichenmiller, Tightening TRIPS: Intellectual Property Provisions of U.S. Free Trade Agreements, in TRADE, DOHA, AND DEVElopment: A Window INTO THE IsSUES 289, 289 (Richard Newfarmer ed., 2006) (discussing the strong intellectual property protections promoted by developed nations such as the U.S. and the concessions the U.S. makes for resisting trade partners, including preferential access to U.S. markets); James Thuo Gathii, Rights, Patents, Markets and the Global AIDS Pandemic, 14 FLA. J. INT'L L. 261, 326-28 (2002) (arguing that the "coercive bargaining framework" of certain international agreements for intellectual property strongly favors developed nations to the detriment of developing nations); Molly Land, Rebalancing TRIPS, 33 MICH. J. INT'L L. 433, 435-36 (2012) (describing how the intellectual property rights requirements imposed by TRIPS can negatively impact the human health and welfare concerns of developing countries); Ruth L. Okediji, Back to Bilateralism? Pendulum Swings in International Intellectual Property Protection, 1 U. OTTAWA L. \& TECH. J. 125, 128 (2004) (indicating that the "mandatory minimum standards of intellectual property protection" in TRIPS allows 
voluminous. ${ }^{3}$ This Article suggests, however, that these debates often miss a more important target.

Intellectual property regimes are widely understood to exist in order to promote the invention, dissemination, and commercialization of intellectual works. ${ }^{4}$ Though attention to this central issue dominates domestic intellectual property discourse, it is almost entirely absent from dialogue concerning the scope and content of international intellectual property law. Refocusing international intellectual property debates on how to increase overall global incentives to innovate could have dramatic social welfare effects. By increasing incentives to innovate, intellectual property law can grow the innovation piepotentially making all countries better off, rather than devolving into adversarial negotiations over how to distribute fixed benefits. ${ }^{5}$

Increasing global incentives to innovate is admittedly a more challenging problem than negotiating over a fixed set of goods or rights. Innovation is a highly complex cognitive and social phenomenon involving significant uncertainty, varied creative and motivational influences, and multiple spillover and feedback dynamics. All of these factors are very difficult to measure or predict. Layered on top of the social phenomena of innovation is the complicated legal system of intellectual property law, muddying the analysis even further. These complexities render the relationship between intellectual property law and innovation hard to parse and difficult to understand. As a consequence, it is often unclear whether any particular change in intellectual property law will tend to increase, decrease, or have no significant effect on incentives to innovate and the level of innovation overall. This indeterminacy is just one reason that states end up bargaining over the domestic effects of intellectual property rights in the international context, rather than truly trying to maximize global incentives to innovate.

Optimizing the net incentives to innovate provided by intellectual property law requires balancing the benefit of the incentives that intellectual property law provides against the costs of exclusivity produced by those very same laws. ${ }^{6}$

developed nations to preserve "traditional guarantees of free trade" while recapturing trade advantages over developing nations with strong manufacturing economies).

${ }^{3}$ See supra notes $1-2$.

${ }^{4}$ See infra Part II.

${ }^{5}$ Identifying the appropriate objectives for countries in international negotiations and disputes is, admittedly, a highly contested topic. See, e.g., Zoe Pearson, Non-Governmental Organizations and the International Criminal Court: Changing Landscapes of International Law, 39 CORNELL INT'L L.J. 243, 244-45 (2006) (exploring the International Criminal Court negotiations as an example of problems with the state-centric model of international law); Celia R. Taylor, A Modest Proposal: Statehood and Sovereignty in a Global Age, 18 U. PA. J. INT'L ECON. L. 745, 751-52, 777-82, 803-04 (1997) (assessing the traditional state-centric model of international law in light of the emerging power of non-state actors in the modern era of globalization).

6 See Mayo Collaborative Servs. v. Prometheus Labs., Inc., 132 S. Ct. 1289, 1293-94, 1305 (2012) (describing the goal of patent protection as desiring to balance the incentives of the promise of exclusive rights against the cost of exclusivity); Sony Corp. of Am. v. 
Though it has proven impossible to measure the trade-offs between incentives and exclusivity directly, it may be possible to do so indirectly. The methodology introduced here is based on considering that a country's preferences for intellectual property rights expressed at the international level are roughly based on an aggregation of the country's domestic preferences for intellectual property rights among its intellectual property producers and consumers. Simplifying for the sake of introduction, to the extent a country produces and exports greater innovation value to foreign entities than the country consumes domestically from foreign industries, the country will favor stronger international intellectual property rights, in an effort to capture for itself the value of such innovation. Conversely, to the extent a country consumes more innovation value than it produces, the country will favor weaker intellectual property rights in an effort to free ride off of the innovation of others. These net-producing and net-consuming countries' preferences for intellectual property law are not driven by a desire to maximize net incentives to innovate globally, but by a desire to maximize the net benefit the country receives individually from intellectual property law.

While most countries will tend to be either net producers or net consumers of innovation, some countries, as a result of their particular industry and consumer composition, will happen to be relatively balanced in their production and consumption of innovation. Balancing the production and consumption interests in innovation is precisely the relationship desired to balance the incentive versus exclusivity trade-off in intellectual property law. Though these balanced countries will be just as self-interested as net-producer and netconsumer countries, their self-interest happens to align with a relationship that will increase net incentives to innovate overall. To the extent these balanced countries' advocacy in international intellectual property debates properly aggregates the interests of their domestic innovation producers and consumers, such countries will tend to naturally desire an intellectual property regime that balances the production and consumption interests in innovation. ${ }^{7}$ An

Universal City Studios, Inc., 464 U.S. 417, 429 (1984) (describing intellectual property as requiring "a difficult balance between the interests of authors and inventors in the control and exploitation of their writings and discoveries on the one hand, and society's competing interest in the free flow of ideas, information, and commerce on the other hand...."); Richard A. Epstein, The Disintegration of Intellectual Property? A Classical Liberal Response to a Premature Obituary, 62 Stan. L. Rev. 455, 458-59 (2010) ("Figuring out how to trade off exclusive ownership that gives strong incentives for commercialization against the free but uncoordinated use of information ... offers the single greatest challenge to preserving the health of the law of copyrights and patents.").

${ }^{7}$ See Susan K. Sell, Private Power, Public Law: The Globalization of INTELLECTUAL PROPERTY RIGHTS 46-51 (2003) (noting the private sector's "expertise and control over information" in relation to intellectual property rights); Peter Drahos, Developing Countries and International Intellectual Property Standard-Setting, 5 J. WORLD INTELL. PROP. 765, 772 (2002) (explaining that private industries often hold superior information regarding intellectual property rights concerns, given the lack of government data). 
intellectual property legal regime that successfully equilibrates these interests will produce the greatest net incentives to innovate for society overall. ${ }^{8}$

Countries with equivalent levels of the production and consumption of innovation should desire, for domestic self-interested reasons, international intellectual property law that balances the trade-off between the incentive benefits and exclusivity costs of intellectual property rights. These countries can effectively serve as proxies for evaluating the level of intellectual property protection that will optimize private incentives to innovate overall. Identifying countries that are relatively balanced in their production and consumption of innovation is not an easy task, but, as discussed below, it is a more manageable challenge than trying to directly understand the relationship between innovation and intellectual property law, and it is a challenge for which we now possess substantial empirical information and data.

Valuable knowledge concerning globally optimal net incentives to innovate can thus be captured by analyzing the relationship between the production and consumption of innovation at the country level. This relationship can be used to signal aggregate private and market information from both innovation industry and innovation consumers concerning the actual benefits and costs of intellectual property rights, information that has never been captured before.

Part II of this Article examines the standard considerations of international intellectual property debates and elucidates why such approaches miss the importance of optimizing overall incentives to innovate. Part III explains the trade-off between incentives and access in intellectual property law, and introduces the proxy signal framework as a new means for identifying how to optimize net incentives to innovate in the international intellectual property law context. Part IV explores how the proxy approach can be applied in international patent law, utilizing the most recent United Nations Commodity Trade Statistics data concerning the production and consumption of innovation by country.

\section{THE INTERNATIONAL POLITICAL ECONOMY OF INTELLECTUAL PROPERTY RIGHTS}

The dominant trope in international intellectual property disputes focuses on intellectual property and trade pressures brought by the United States, the European Union, Japan, and other technologically advanced countries to strengthen intellectual property regimes. ${ }^{9}$ The BRIC countries ${ }^{10}$ and other

\footnotetext{
${ }^{8}$ See infra Part II.

${ }^{9}$ See $\mathrm{Yu}$, Middle Intellectual Property Powers, supra note 1, at 84; Bird \& Cahoy, supra note 1, at 403; Gene M. Grossman \& Edwin L.-C. Lai, International Protection of Intellectual Property, 94 AM. ECON. REV. 1635, 1635 (2004); Okediji, supra note 2, at 128; Walter G. Park, International Patent Protection: 1960-2005, 37 RES. POL'y 761, 762-64 (2008); Bruno Salama \& Daniel Benoliel, Pharmaceutical Patent Bargains: The Brazilian Experience, 18 CARDOZO J. INT'L \& COMP. L. 633, 644-52 (2010); Ullrich, supra note 1, at 427.
} 
developing states have pushed back to varying degrees, but have also often acquiesced in exchange for certain trade relations or foreign investment. ${ }^{11}$ The political economy of these debates is well-studied, and the motivations behind the disputes are relatively straightforward. Private industry in technologically advanced countries can profit from the opportunity to charge higher prices for intellectual property-protected products in foreign markets, while parties in developing countries bear the expense of exclusionary intellectual property rights and have limited opportunity to profit from selling their own intellectual property products abroad. ${ }^{12}$ Consequently, a strong international intellectual property rights regime is generally economically advantageous to technologically advanced countries.

There have been many high-profile examples of international intellectual property disputes along these lines over the past several decades. The United States, the European Union, and Japan led the press for the Agreement on Trade Related Aspects of Intellectual Property Rights ${ }^{13}$ (TRIPS), the most comprehensive international intellectual property rights treaty, over the initial objections of India, Brazil, and a number of other developing countries. ${ }^{14}$ The United States has used trade pressure and threats of various sanctions to compel Brazil to strengthen patent protection for pharmaceuticals, to drive Russia to adopt intellectual property protection for computer programs, and to push China to implement stronger patent protection and enforcement. ${ }^{15}$ More recently, both the United States and the European Union have used their trade power to negotiate bilateral and other free trade agreements with a number of developing countries that require the adoption of stronger domestic intellectual property protection regimes than is mandated by TRIPS or other international intellectual property treaties. ${ }^{16}$

${ }^{10} \mathrm{BRIC}$ is an acronym that refers to Brazil, Russia, India, and China, all rising economic powers on the global stage.

${ }^{11} \mathrm{Yu}$, Middle Intellectual Property Powers, supra note 1, at 100-02; Bird \& Cahoy, supra note 1, at 403; Salama \& Benoliel, supra note 9, at 644-53.

${ }^{12} \mathrm{Yu}$, Middle Intellectual Property Powers, supra note 1, at 87-88; Park, supra note 9, at 764; Suzanne Scotchmer, The Political Economy of Intellectual Property Treaties, 20 J.L. ECON. \& ORG. 415, 418 (2004).

13 Agreement on Trade-Related Aspects of Intellectual Property Rights, Apr. 15, 1994, 33 I.L.M. 1197, 1869 U.N.T.S. 299.

${ }^{14} \mathrm{Yu}$, Middle Intellectual Property Powers, supra note 1, at 100; Robert C. Bird, Defending Intellectual Property Rights in the BRIC Economies, 43 AM. Bus. L.J. 317, 32229 (2006); Bird \& Cahoy, supra note 1, at 403; Joseph E. Stiglitz, Economic Foundations of Intellectual Property Rights, 57 DUKE L.J. 1693, 1695 n.7 (2008).

15 Bird, supra note 14 , at 327-31.

${ }^{16} \mathrm{Yu}$, Middle Intellectual Property Powers, supra note 1, at 88-89; Fink \& Reichenmiller, supra note 2, at 289; Arnold, supra note 1, III 9-11; Amy Kapczynski, The Access to Knowledge Mobilization and the New Politics of Intellectual Property, 117 YALE L.J. 804, 825 (2008); Okediji, supra note 2, at 128-29; Raymundo Valdés \& Runyowa Tavengwa, Intellectual Property Provisions in Regional Trade Agreements 18-19 (World Trade Org., Working Paper No. ERSD-2012-21, 2012); Rohan K. George, Does One Size Fit All? A Comparative Study to Determine an Alternative to International Patent 
Though these and other international intellectual property disputes have been well-studied, ${ }^{17}$ generally overlooked in the political economy analysis is the focus that should be the central objective of intellectual property rights: optimizing the incentives and environment for innovation. ${ }^{18}$ At the domestic level, on the other hand, optimizing incentives to innovate is commonly recognized as the dominant goal of intellectual property law in most policy arguments and analyses, both by those who favor stronger intellectual property protection and by those who argue that weaker intellectual property rights would strengthen the environment for innovation. ${ }^{19}$ The reason for this focus in national law is that at the domestic level states both reap the benefit of the incentives created by their intellectual property regimes and bear the burden of the costs of exclusion produced by the regime. As a consequence, states roughly internalize both the positive and negative externalities of domestic intellectual property law, ${ }^{20}$ and therefore seek a national intellectual property legal regime that balances these interests so as to optimize the incentives to innovate.

The international political economy of intellectual property rights is different. Domestic self-interest makes profits earned abroad from intellectual property rights an unmitigated benefit. ${ }^{21}$ As opposed to the national law sphere where domestic consumers must bear the burden of intellectual property rights, foreign-borne limitations on access or consumer deadweight losses created by intellectual property rights are effectively irrelevant to domestic political

Harmonization 7-8 (Cornell Law School Inter-University Graduate Student Conference Papers, Paper No. 28, 2009).

17 See supra note 1.

18 See Grossman \& Lai, supra note 9, at 1636 (noting the failure of prior literature to consider what international intellectual property regime would be globally most efficient). Countries certainly sometimes frame their arguments as promoting innovation overall, but such frames are usually more rhetorical, rather than being based on any actual intent or interest in maximizing global incentives to innovate. See Kapczynski, supra note 16, at 848-49 (noting TRIPS advocates' claims that TRIPS would be beneficial for developing, as well as developed, countries); Keith E. Maskus, Lessons from Studying the International Economics of Intellectual Property Rights, 53 VAND. L. REV. 2219, 2220 (2000) (noting advocacy by supporters of both weaker and stronger intellectual property rights based on the overall effects of given policy on innovation).

${ }^{19}$ E.g., James Bessen \& Michael J. Meurer, Patent Failure: How Judges, BurEaucrats, AND LAWYERS Put INNOVATORS AT RisK 11-12 (2008); DAN L. BurK \& Mark A. Lemley, The Patent Crisis and How the Courts Can Solve It 100-02 (2009); Dan L. Burk \& Mark A. Lemley, Policy Levers in Patent Law, 89 VA. L. REV. 1575, 159799 (2003).

${ }^{20}$ Gregory N. Mandel, Proxy Signals: Capturing Private Information for Public Benefit, 90 WASH. U. L. REV. 1, 57 (2012). This internalization is only approximate, as intellectual property law cannot internalize all of the benefits and costs of innovation. Brett M. Frischmann \& Mark A. Lemley, Spillovers, 107 CoLUM. L. REV. 257, 276-82 (2007) (discussing various spillover benefits of innovation that are not internalized by intellectual property law).

${ }^{21}$ Scotchmer, supra note 12 , at 418. 
economy interests. ${ }^{22}$ These innovation and market externalities mean that there is effectively a market failure in the international political economy of intellectual property, when viewed from the perspective of trying to optimize global incentives to innovate. ${ }^{23}$ As a result, there is no reason to believe that the positions pressed by any particular state acting in its own best interests in international fora will necessarily align with the international intellectual property regime that would best incentivize innovation globally. ${ }^{24}$

There is a certain irony to the reality that optimizing net incentives to innovate is generally ignored in international intellectual property debates. International agreements can only come into existence if all parties to the agreement determine that it is in their own best interests. ${ }^{25}$ Simply shifting intellectual property rights profit flows from one state to another cannot achieve this objective. ${ }^{26}$ The fact that shifting profit flows cannot make all states better off is why trade rights and promises of foreign direct investment are often linked to intellectual property agreements. ${ }^{27}$ Offering these external benefits is the only way that countries that desire stronger intellectual property rights (and the concomitant increased profit flows) can entice parties who feel they will get short-changed by stronger protection to join the agreement. ${ }^{28}$ Rather than simply shifting profit flows, however, an intellectual property agreement that actually increases incentives to innovate globally could produce true efficiency gains. These gains could serve as the basis for international intellectual property rights treaties that do not require side-deal sweeteners because they actually directly increase the welfare of all party states. ${ }^{29}$

${ }^{22}$ See Scotchmer, supra note 12, at 420 (discussing the market failure created by domestic producers not taking into account foreign consumer deadweight losses).

${ }^{23}$ See SuZAnne Scotchmer, InNOVATION AND InCENTIVES 332-33 (2004); Salama \& Benoliel, supra note 9 , at 635-36.

${ }^{24}$ SCOTCHMER, supra note 23, at 332-33; Maskus, supra note 18, at 2222.

${ }^{25}$ Kenneth W. Abbott \& Duncan Snidal, Why States Act Through Formal International Organizations, 42 J. CONFLICT RESOL. 3, 10-11 (1998); Jack L. Goldsmith \& Eric A. Posner, International Agreements: A Rational Choice Approach, 44 VA. J. INT'L L. 113, 120-21 (2003); Kal Raustiala, Form and Substance in International Agreements, 99 AM. J. INT'L L. 581, 609 (2005).

${ }^{26}$ Scotchmer, supra note 12 , at 421-22.

27 See supra note 11.

${ }^{28}$ Rachel Brewster, The Surprising Benefits to Developing Countries of Linking International Trade and Intellectual Property, 12 CHI. J. INT'L L. 1, 5 (2011) (explaining how the U.S. and European nations made the TRIPS agreement more attractive to developing countries concerned about stronger intellectual property rights through advantageous trade measures for developing countries); Okediji, supra note 2, at 144 (discussing the role of trade negotiations as central to the benefits developing countries gain in joining international intellectual property agreements such as TRIPS).

${ }^{29}$ See Scotchmer, supra note 12, at 421-22. 


\section{Countries AS InTEllectual Property Proxies}

Optimizing incentives to innovate globally is commonly believed to require understanding the relationship between intellectual property rights and innovation, a seemingly impossible task. ${ }^{30}$ Innovation is too complex and stochastic a phenomena, both cognitively and socially, and the effects of intellectual property law are too complicated and dynamic to ever parse this relationship directly. Rather than trying to understand the relationship between intellectual property law and innovation directly, however, the approach introduced here proposes a novel framework that uses signals from private and market activity to indirectly reveal the structure of this relationship. These proxy signals can then be leveraged to identify which intellectual property laws are more likely to increase global incentives to innovate.

The analysis that follows assumes national treatment of intellectual property law. ${ }^{31}$ That is, it assumes that each country offers the same intellectual property protection to both domestic and foreign entities. This assumption is relatively accurate, as national treatment of intellectual property rights is mandated by numerous treaties to which nearly all countries adhere. ${ }^{32}$

For the purposes of introducing the international proxy signal methodology, the analysis below focuses on patent law, as opposed to intellectual property law generally. An equivalent analysis could be applied to copyright law. ${ }^{33}$

\footnotetext{
${ }^{30}$ Keith e. Maskus, Intellectual Property Rights In the Global ECONOMY 6-7 (2000); Robert P. Merges, Justifying Intellectual Property 2 (2011) (referring to balancing the costs and benefits of intellectual property as "impossibly complex").

${ }^{31}$ See Grossman \& Lai, supra note 9, at 1636 (making the same assumption); Scotchmer, supra note 12, at 422 (making the same assumption).

32 Agreement on Trade-Related Aspects of Intellectual Property Rights, Apr. 15, 1994, 33 I.L.M. 1197, 1869 U.N.T.S. 299; Berne Convention for the Protection of Literary and Artistic Works, Sept. 9, 1886, 25 U.S.T. 1341, 828 U.N.T.S. 221, available at http://www.wipo.int/treaties/en/ip/paris/, archived at http://perma.cc/XM6G-DDEG (166 signatories); Paris Convention for the Protection of Industrial Property, Mar. 20, 1883, 21 U.S.T. 1583, 828 U.N.T.S. 305, available at http://www.wipo.int/treaties/en/ip/paris/, archived at http://perma.cc/8ZDP-X545 (174 signatories).

33 Proxy signal analysis is equally applicable to copyright law to the extent copyright law is understood to focus on incentives to create and commercialize copyrightable works. Shyamkrishna Balganesh, Foreseeability and Copyright Incentives, 122 HARV. L. REV. 1569, 1571 (2009); See also Metro-Goldwyn-Mayer Studios Inc. v. Grokster, Ltd., 545 U.S. 913, 932 (2005) (citing the shared underpinnings of copyright and patent law in incentivizing the promotion of innovation); Sony Corp. of Am. v. Universal City Studios, Inc., 464 U.S. 417, 442 (1984) (same); Michael D. Birnhack, Copyright Law and Free Speech After Eldred v. Ashcroft, 76 S. CAL. L. REV. 1275, 1295 (2003) (articulating that the purpose of copyright law is to promote the progress of science, which is realized by the dissemination, access, and use of knowledge, in part by granting property rights to authors to control the use of their works); Erwin Chemerinsky, Balancing Copyright Protections and Freedom of Speech: Why the Copyright Extension Act Is Unconstitutional, 36 LOY. L.A. L. REV. 83, 88 (2002) (stating that the right of an individual to profit from their work is a goal of both patent and copyright law).
} 
Unlike patent and copyright, trademark law is not generally understood to seek optimal incentives to innovate, and therefore presents a somewhat different matter. ${ }^{34}$ The analysis also begins with the assumption of globally harmonized intellectual property law. This assumption is relatively accurate in certain regards, as the forces of TRIPS, trade pressure, and other factors have led many countries to adopt remarkably similar domestic patent law systems. ${ }^{35}$ That said, intellectual property law is not perfectly harmonized across jurisdictions at the detailed level, as differences (including some significant ones) among various countries exist. ${ }^{36}$ For example, there are differences across jurisdictions in the scope of subject matter that is patent-eligible, 37 in standards for patent validity, ${ }^{38}$ and in the treatment of pharmaceutical patenting. ${ }^{39}$ The assumption of globally harmonized intellectual property law is relaxed in certain regards later in the article. ${ }^{40}$

34 See J. THOMAS MCCARTHY, MCCARTHY ON TRADEMARKS AND UNFAIR COMPETITION $\S 2.1$ (4th ed. 2008) (stating there is a long history of trademark protecting both consumers and sellers by facilitating competition, which benefits both parties); Mark P. McKenna, The Normative Foundations of Trademark Law, 82 NoTRE DAME L. REV. 1839, 1840-41 (2007) (contending that the central interest of trademark law is to prevent the illegitimate diversion of consumers from producers). Despite the differences in the objectives of trademark law, the underlying procedure of proxy analysis, identifying entities that balance desired tradeoffs, could be applied to trademark law.

${ }^{35}$ Yu, Middle Intellectual Property Powers, supra note 1, at 88-89; Land, supra note 2, at 435-36; Salama \& Benoliel, supra note 9, at 665; Amy Kapczynski, Harmonization and Its Discontents: A Case Study of TRIPS Implementation in India's Pharmaceutical Sector, 97 CALIF. L. REV. 1571, 1574 (2009); Park, supra note 9, at 762; Grossman \& Lai, supra note 9, at 1649; Scotchmer, supra note 12, at 420. Efforts to harmonize intellectual property rights internationally have a long history, dating back at least to the Berne Convention of 1886, which harmonized protection among signatory countries for certain intellectual property rights, though mostly procedurally. Berne Convention for the Protection of Literary and Artistic Works, Sept. 9, 1886, 25 U.S.T. 1341, 828 U.N.T.S. 221, available at http://www.wipo.int/treaties/en/ip/paris/, archived at http://perma.cc/XM6G-DDEG.

36 See generally Sunil Kanwar \& Robert Evenson, On the Strength of Intellectual Property Protection that Nations Provide, 90 J. DEV. ECON. 50 (2009) (discussing variation in substantive patent law across various countries); Lyndon DeSalvo, First Among BRICs: Brazil's Necessary Challenging of TRIPs (March 2010) (unpublished B.A. thesis, Carleton College), available at http://people.carleton.edu/ amontero/Lyndon\%20DeSalvo.pdf, archived at http://perma.cc/BQ7Q-9W4J; ROBERT LEWIS-LETTINGTON \& PETER MUNYI, DFID Health Systems Resource Centre, Willingness and AbIlity to Use TRIPs FLEXIBILITIES: KENYA CASE STUDY (2004), available at http://www.who.int/hiv/amds/countries/ken_UseTRIPsFlexibilitiesDFID.pdf.

${ }^{37}$ Kanwar \& Evenson, supra note 36, at 50. The United States, Japan, Australia, and New Zealand generally provide patent protection for a greater scope of subject matter than other countries. $I d$.

38 Paul Goldstein \& Marketa Trimble, InTERnational Intellectual Property LAW: CASES AND MATERIALS 403-54 (3d ed. 2012).

${ }^{39}$ Id.; DeSalvo, supra note 36, at 1; Lewis-Lettington \& Munyi, supra note 36, at 9.

${ }^{40}$ See infra Part III.B. The assumption is only relaxed with respect to allowing differential intellectual property law across different industries. Infra Part III.B. Note that 
Finally, it is worth noting that proxy signal analysis focuses on maximizing aggregate incentives to innovate globally. ${ }^{41}$ Maximizing incentives to innovate, so as to optimize overall innovation, is admittedly not the same as maximizing the social welfare from innovation. ${ }^{42}$ Maximizing incentives to innovate, however, is a commonly used surrogate, ${ }^{43}$ and should serve as a valuable first step towards increasing overall social welfare.

\section{A. Patent Law Objectives}

It is generally accepted that the primary objective of patent law is to incentivize innovation. ${ }^{44}$ Absent patent protection, the non-rivalrous and nonexclusive nature of innovation would lead to a market failure in innovation efforts and activity. ${ }^{45}$ Potential inventors would not put the socially optimal level of effort and of resources into innovation because once an invention was publicly disclosed, competitors and consumers could free ride and copy it at will, reducing the inventor's ability to profit from the invention. ${ }^{46}$ Patent law seeks to solve this market failure through the grant of exclusionary patent

there is no reason to expect that the harmonization of patent protection internationally is necessary for optimizing net incentives to innovate globally. In fact, it is highly likely that such harmonization would not efficiently maximize incentives. Grossman \& Lai, supra note 9 , at $1649-50$.

${ }^{41}$ See Grossman \& Lai, supra note 9, at 1637 (defining an efficient patent regime as "one that provides the optimal aggregate incentives for innovation to inventors throughout the world.").

42 BESSEN \& MEURER, supra note 19, at 11-12; Burk \& Lemley, supra note 19, at $1580-81$.

${ }^{43}$ BESSEN \& MEURER, supra note 19, at 11-12; Burk \& Lemley, supra note 19, at 1580-81. The actual social welfare produced by innovation would be extremely difficult to measure. David S. Abrams, Did TRIPS Spur Innovation? An Analysis of Patent Duration and Incentives to Innovate, 157 U. PA. L. REV. 1613, 1616 (2009).

${ }^{44}$ BURK \& LEMLEY, supra note 19, at 67 ("[T]heories of patent law based on moral right, reward, or distributive justice ... are hard to take seriously as explanations for the actual scope of patent law."); see also Burk \& Lemley, supra note 19, at 1576 ("Patent law is our primary policy tool to promote innovation...."); Robert Cooter et al., The Importance of Law in Promoting Innovation and Growth, in RULES FOR GROWTH: Promoting InNOvation And Growth Through Legal Reform 1, 3 (The Kauffmann Task Force on Law, Innovation, \& Growth ed., 2011) (discussing empirical work showing that innovation is the most important factor of production for economic growth in the United States).

45 See, e.g., Kewanee Oil Co. v. Bicron Corp., 416 U.S. 470, 480-81 (1974) (discussing how the prospect of obtaining a patent monopoly provides an incentive to invest in efforts to create new inventions); RICHARD A. POSNER, ECONOMIC ANALYSIS OF LAW 48-59 (8th ed. 2011).

${ }^{46}$ BESSEN \& MEURER, supra note 19, at 29-32, 34-35; Herbert Hovenkamp, Competition for Innovation, 2012 COLUM. BuS. L. REV. 799, 800. 
rights. ${ }^{47}$ Exclusionary patent rights provide an inventor with monopoly pricing power that allows the inventor to charge a price for her or his invention which more closely approaches the value that a consumer places on the invention, rather than the free-market cost of production. ${ }^{48}$ Patent rights thus enable inventors to profit off of innovation to the extent of the private value of use of the innovation, bringing the private benefits of invention more in line with their social value. ${ }^{49}$ This internalization of innovation externalities provides inventors with incentives to invest time, financial resources, and effort into the research, development, and commercialization of innovation.

This incentive theory of patent rights, however, only tells half of the story because patent protection is a dual-edged sword. Patent rights not only provide incentives to innovate, they also limit access to patented products by increasing their price. ${ }^{51}$ Increasing the price of intellectual property works reduces the distribution of such innovation and reduces the opportunity for future technological development that improves or builds upon the patented innovation. ${ }^{52}$ Thus, while patent laws that are too weak will limit incentives to invest resources and innovate in the first instance, patent laws that are too strong create their own barriers to innovation, stifling the further development and dissemination of innovation products.

The goal of patent law is to set a level of patent protection that appropriately balances the competing trade-offs between the benefit of incentives and the cost of limiting access so as to achieve the greatest aggregate net incentives to innovate for society overall. ${ }^{53}$ The following sections consider

47 See MERGES, supra note 30, at 154; BESSEN \& MEURER, supra note 19, at 30-31; Nancy Gallini \& Suzanne Scotchmer, Intellectual Property: When Is It the Best Incentive System?, in 2 InNovation Policy And THE Economy 51-53, 63 (Adam B. Jaffe, Josh Lerner \& Scott Stern eds., 2002).

${ }^{48}$ See Kenneth Arrow, Economic Welfare and the Allocation of Resources for Invention, in THE RATE AND DiRECTION OF INVENTIVE ACTIVITY: ECONOMIC AND SOCIAL FACTORS 609, 615 (Nat'l Bureau of Econ. Res., 1962).

${ }^{49}$ Id. at 623; F. Scott Kieff, Property Rights and Property Rules for Commercializing Inventions, 85 MINN. L. REV. 697, 710 (2001); Mark A. Lemley, Ex Ante Versus Ex Post Justifications for Intellectual Property, 71 U. CHI. L. REV. 129, 133 (2004).

${ }^{50}$ See Rebecca S. Eisenberg, Patents and the Progress of Science: Exclusive Rights and Experimental Use, 56 U. CHI. L. REV. 1017, 1024 (1989).

51 See BESSEN \& MEURER, supra note 19, at 30-32; Gallini \& Scotchmer, supra note 47 , at 54 .

52 William D. Nordhaus, Invention, Growth, and Welfare: A Theoretical Treatment of TeChnOlogical Change 88-90 (1969); Abrams, supra note 43, at 1615; Robert P. Merges \& Richard R. Nelson, On the Complex Economics of Patent Scope, 90 Colum. L. REV. 839, 839 (1990); see also Bilski v. Kappos, 561 U.S. 593, 609 (2010) ("These [patent validity] limitations serve a critical role in adjusting the tension, ever present in patent law, between stimulating innovation by protecting inventors and impeding progress by granting patents when not justified ....").

53 See Mayo Collaborative Servs. v. Prometheus Labs., Inc., 132 S. Ct. 1289, 1305 (2012); BESSEN \& MEURER, supra note 19, at 11-12 (identifying the goal of maximizing net incentives to innovate); NoRDHAUS, supra note 52, at 88-90; F.M. Scherer, The Economic 
this incentive versus access trade-off in greater depth and examine past attempts to identify the optimal balance between them.

\section{B. The Relationship Between Patent Law and Innovation}

Patent rights provide an incentive to innovate and simultaneously reduce access to current and future innovation. The former presents a potentially great social benefit; the latter a potentially great social cost. Patent law's incentives to innovate include not just the direct potential of supracompetitive profits, but also a number of other benefits that have been identified, including the opportunity for firms to signal their technological strength, ${ }^{54}$ reduce transaction costs, ${ }^{55}$ and price-coordinate. ${ }^{56}$ If patent rights are too limited or too weak, potential innovators will face suboptimal incentives to invest resources and time in innovation-producing activities in the first instance. ${ }^{57}$ Too little innovation will occur.

If patent rights are too expansive or too strong, however, potential innovators may face reduced incentives to innovate as well. ${ }^{58}$ The grant of patent rights affects the value and feasibility of future innovation because it increases the cost of using the intellectual property of others, due to greater licensing and litigation expenses, and reduces incentives for follow-on improvement innovation, as any potential profit must now be shared. ${ }^{59}$ In addition, greater propertization can increase the likelihood of patent thickets ${ }^{60}$ and anticommons effects, ${ }^{61}$ each creating costs that reduce the benefit of, and

Effects of Compulsory Patent Licensing, in THE MONOGRAPH SERIES IN FINANCE AND ECONOMICS 84 (Edwin J. Elton \& Martin J. Gruber eds., 1977) ("The problem of patent policy is to strike a balance: enough protection to sustain a desired flow of innovations, but not superfluous protection in view of alternate incentives for innovation and the social burdens monopoly power imposes.").

${ }^{54}$ Clarisa Long, Patent Signals, 69 U. CHI. L. ReV. 625, 627-28 (2002).

55 William M. Landes \& Richard A. Posner, The Economic Structure of INTELLECTUAL PROPERTY LAW 12-13, 318-25 (2003).

56 Douglas Lichtman, Property Rights in Emerging Platform Technologies, 29 J. LEGAL STUD. 615, 619-20 (2000).

57 See BESSEN \& MEURER, supra note 19, at 11.

${ }^{58}$ Lab. Corp. of Am. Holdings v. Metabolite Labs., Inc., 548 U.S. 124, 126 (2006) (Breyer, J., dissenting) ("[S]ometimes too much patent protection can impede rather than 'promote the Progress of Science and useful Arts ....'" (quoting U.S. CONST. art. I, § 8, cl. 8)).

${ }^{59}$ See Nordhaus, supra note 52, at 76; Jonathan M. Barnett, Property As Process: How Innovation Markets Select Innovation Regimes, 119 YALE L.J. 384, 407 (2009); Merges \& Nelson, supra note 52, at 839, 886-88.

${ }^{60}$ Carl Shapiro, Navigating the Patent Thicket: Cross Licenses, Patent Pools, and Standard Setting, in 1 InNOVATION POLICY \& THE ECONOMY 119, 119 (2000). Patent thickets refer to the high transactions costs of having to navigate a field in which there are numerous overlapping patents held by numerous entities. $I d$.

${ }^{61}$ Michael A. Heller \& Rebecca S. Eisenberg, Can Patents Deter Innovation? The Anticommons in Biomedical Research, 280 SCIENCE 698, 698-700 (1998). Anticommons 
incentives for, innovation. Somewhere between the extremes of no patent incentives and excessive barriers to access lies a level of propertization that can maximize the aggregate net incentives to innovate for society.

In trying to optimize the trade-off between incentives and exclusivity, increases in the level of patent protection have two primary effects: they increase the incentives for innovators to innovate due to the potential for greater supracompetitive profits (thus increasing innovation activity) and simultaneously reduce incentives to innovate due to the grant of greater exclusive rights to others (thus reducing innovation activity). Starting from a point of no patent protection, so long as the marginal benefit of greater incentives outweighs the marginal cost of greater exclusion, increasing patent protection will increase incentives to innovate overall. As patent rights increase, however, the marginal benefit of increased incentives will tend to get smaller due to decreasing returns to scale, ${ }^{62}$ while the marginal cost of exclusionary rights will tend to increase due to the increased transaction costs of the network effects of greater exclusivity. ${ }^{63}$ As a result, the relationship between a given level of patent protection and the corresponding net incentives or value of innovation produced by that level of propertization will have an inverted-U form, as presented in Figure 1.64

refers to the situation where too many private rights holders own patents in an area such that it is expensive to identify who owns which rights or what subject matter can be practiced. Id.

${ }^{62}$ See Frischmann \& Lemley, supra note 20, at 258 (noting the decreasing returns to scale of incentives).

${ }^{63}$ See Barnett, supra note 59, at 411 (noting that "as the level of propertization increases, marginal transaction costs accelerate").

${ }^{64}$ See Jonathan M. Barnett, Do Patents Matter? Empirical Evidence on the Incentive Thesis, in HANDBOOK ON LAW, INNOVATION AND GROWTH 178, 191 (Robert E. Litan ed., 2011) (presenting cross-country evidence for an inverted-U relationship); Christopher A. Cotropia \& James Gibson, The Upside of Intellectual Property's Downside, 57 UCLA L. REV. 921, 932-33 (2010) (presenting a similar approach); Nancy T. Gallini, The Economics of Patents: Lessons from Recent U.S. Patent Reform, 16 J. ECON. PERSP. 131, 136-39 (2002) (discussing empirical support for an inverted-U relationship). 
Figure 1: Intellectual Property Law and Innovation

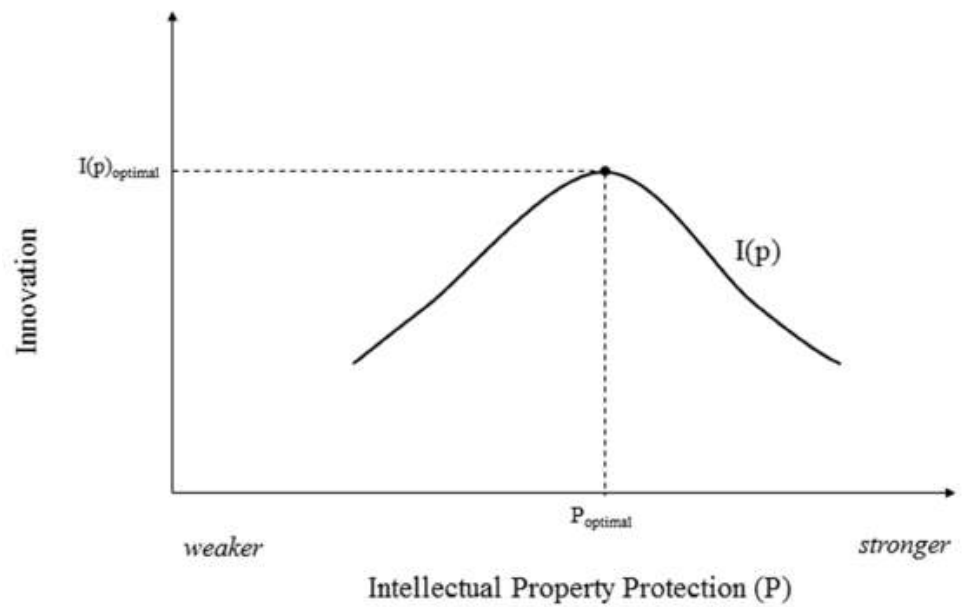

Given any level of patent protection $(\mathrm{P})$, the net incentives for innovation produced by that level of protection are denoted by the function $\mathrm{I}(\mathrm{p})$. Patent law regimes towards the left side of Figure 1 represent commons-style approaches with weaker propertization; regimes towards the right side represent exclusivity approaches with stronger propertization. The innovation function's maximum, labeled $\mathrm{P}_{\text {optimal }}$ in Figure 1, represents the level of propertization that will maximize the cumulative net incentives to innovate for society globally. ${ }^{65} \mathrm{At}$ $\mathrm{P}_{\text {optimal }}$ the marginal benefit of increased incentives is exactly equal to the

65 See Abrams, supra note 43, at 1615 (explaining that "[t]he optimal patent term is that point at which the marginal benefit from increased innovation is exactly offset by the marginal cost of the deadweight loss created by the patent right"). Figure 1 depicts the strength of patent protection as a single metric, displayed along its $\mathrm{x}$-axis. In practice, any given level of patent protection is made up of a number of components, including the scope, duration, and enforceability of patent rights. Cotropia \& Gibson, supra note 64, at 932 (making this point with respect to several aspects of intellectual property protection); John M. Golden, Principles for Patent Remedies, 88 TEX. L. REV. 505, 526 (2010) (listing a number of components of patent rights). Sometimes, strengthening certain elements, while weakening others, could produce a socially superior patent regime, though it may be unclear whether such a regime represents "stronger" or "weaker" propertization. One can imagine a more complex, multi-dimensional version of Figure 1 that takes into account these different components, in which the innovation function is no longer a two-dimensional curve, but a multi-dimensional form. For purposes of initial explanation, it is convenient to conceptualize patent propertization strength as ordered along a single dimension, considering each point along the axis to represent a set of patent rights, involving, for example, particular scope and duration of rights. Cotropia \& Gibson, supra note 64, at 933 (making the same assumption). This simplification is for ease of introduction only and is not necessary for proxy signal analysis. Cotropia \& Gibson, supra note 64, at 933 n.32. 
marginal cost of greater exclusivity. ${ }^{66}$ Beyond this "sweet spot," increases in the strength of patent protection tend to reduce net incentives to innovate as the marginal cost of exclusionary rights outweighs the marginal benefit of increased incentives. ${ }^{67}$ Though Figure 1 happens to display the optimal level of propertization towards the middle of the function, this is for presentation purposes only, and has no effect on the analysis that follows.

The foregoing presents the theory and policy behind patent protection. In practice, we could never allocate rights so precisely as to achieve the optimal level of protection. ${ }^{68}$ Even if society found itself exactly at the optimal level, it is unlikely that we would know. ${ }^{69}$ Further, even if we could achieve the optimal level momentarily, critical real world context, including innovation and industries, evolves dynamically, so the optimal target will change over time. We can, however, try to develop a patent system that approaches the optimal level to the greatest extent possible.

\section{Conventional Approaches to Optimizing Patent Rights}

Academics and other experts in many fields have spent decades trying to understand where the sweet spot of patent protection lies in order to achieve the optimal level of net incentives to innovate in the domestic context. There have been many ambitious and creative attempts to solve this complex empirical problem. Past and ongoing efforts include advanced conceptual frameworks, ${ }^{70}$ complex theoretical models, ${ }^{71}$ comparisons of innovation across jurisdictions with differing intellectual property protection, ${ }^{72}$ and studies of changes in

66 NORDHAUS, supra note 52, at 78.

${ }^{6}$ See Tim Wu, Intellectual Property, Innovation, and Decentralized Decisions, 92 VA. L. REV. 123 (2006) ("[I]ntellectual property grants are desirable to the extent that they encourage new product development at a reasonable cost.").

${ }^{68}$ Because innovation is a public good, even defining the socially optimal level of incentives to innovate is a complex task. See BretT M. Frischmann, INFRASTRUCTURE: THE Social VALUE OF SHARED RESOURCES 53-57 (2012) (discussing challenges of pursuing optimality for public goods).

${ }^{69}$ See B. Curtis Eaton \& Richard G. Lipsey, Product Differentiation, in 1 HANDBOOK OF INDUSTRIAL ORGANIZATION 723, 760 (Richard Schmalensee \& Robert Willig eds., 1989) (noting in a comparable market context that "we believe that we would be quite unable to recognize an optimum if we saw one").

${ }^{70}$ E.g., SCOTCHMER, supra note 23, at 319-50; Heller \& Eisenberg, supra note 61, at 698; Edmund W. Kitch, The Nature and Function of the Patent System, 20 J.L. \& ECON. 265, 276-77 (1977); Merges \& Nelson, supra note 52, at 840.

${ }^{71}$ E.g., NordHAUS, supra note 52, at 88-90; James Bessen \& Eric Maskin, Sequential Innovation, Patents, and Imitation, 40 RAND J. ECON. 611-14 (2009); Partha Dasgupta \& Joseph Stiglitz, Uncertainty, Industrial Structure, and the Speed of R\&D, 11 BELL J. ECON. 1 (1980); Robert M. Hunt, Patentability, Industry Structure, and Innovation, 52 J. INDUS. ECON. 401 (2004).

72 E.g., ERIC SchifF, Industrialization Without NATional Patents: The NETHERLANDS, 1869-1912; SwITZERLAND, 1850-1907 (1971); Josh Lerner, 150 Years of Patent Protection, 92 AM. Econ. ReV. 221 (2002); Petra Moser, How Do Patent Laws 
innovation due to changes in intellectual property laws over time. ${ }^{73}$ Though these approaches include many extraordinarily sophisticated endeavors, each has been unable to identify the optimal level of patent protection for at least one (and often multiple) of the following reasons: (1) they cannot sufficiently take into account all of the real world factors influencing innovation and incentives, ${ }^{74}$ (2) they cannot identify or control for the pertinent factors that influence innovation in real world studies, ${ }^{75}$ or (3) they consider only a limited area of innovation. ${ }^{76}$ Though we have learned much about innovation and patent law from these efforts, our understanding of the relationship between innovation and law remains frustratingly inconclusive. ${ }^{77}$

Influence Innovation? Evidence from Nineteenth-Century World's Fairs, 95 AM. ECON. REV. $1214(2005)$.

${ }^{73}$ E.g., Abrams, supra note 43, at 1613; James Bessen \& Robert M. Hunt, An Empirical Look at Software Patents, 16 J. Econ. \& MGMT. STRATEgy 157 (2007); Aaron S. Kesselheim, Using Market-Exclusivity Incentives to Promote Pharmaceutical Innovation, 363 NEw ENG. J. MED. 1855, 1856 (2010); Moser, supra note 72, at 1216-17; Mark A. Lemley, An Empirical Study of the Twenty-Year Patent Term, 22 AIPLA Q.J. 369 (1994); Mariko Sakakibara \& Lee Branstetter, Do Stronger Patents Induce More Innovation? Evidence from the 1988 Japanese Patent Law Reforms, 32 RAND J. ECON. 77 (2001).

${ }^{74}$ E.g., SCOTCHMER, supra note 23 , at 32-40 (discussing the difficulty and lack of information for evaluating the pioneer versus improver balance of rights in conceptual models); Abrams, supra note 43, at 1616-25 (discussing the difficulty of measuring innovation); Bessen \& Maskin, supra note 71, at 614-19 (providing one of the most sophisticated economic models to date, but noting inaccurate assumptions that no firms own patents ex ante and that the social value of an invention is known); Peter S. Menell, $A$ Method for Reforming the Patent System, 13 Mich. TeleCOMM. \& TECH. L. REV. 487, 489 (2007) (providing a laundry list of some of the factors that would need to be taken into account in an economic model of optimizing patent protection). Simplifying assumptions are, in fact, one of the hallmarks and benefits of economic modeling. See COLIN F. CAMERER, WORLD CONG. OF THE ECONOMETRIC SOC'Y, BEHAVIORAL ECONOMICS 6 (2011), http://www.hss.caltech.edu/ camerer/index.htm, archived at http://perma.cc/3XND-D35W.

${ }^{75}$ E.g., William J. Baumol, The Free-Market InNovation Machine: ANALyzing THE GROWTH MiRACLE OF CAPITALISM 296 (2002) (noting difficulty with measuring or establishing the cause of innovation); SCHIFF, supra note 72, at 43, 51, 102-06 (noting problems with measuring innovation and with comparing real world studies across time or jurisdiction); G. M. PeTER SwANN, THE ECONOMICS OF INNOVATION: AN INTRODUCTION 3536 (2009) (describing limitations of various approaches to measuring innovation); Abrams, supra note 43, at 1615-19, 1640-41 (noting problems with evaluating exogenous effects on innovation and with the data used to measure innovation); Lerner, supra note 72, at 224 (noting problems with data used to measure innovation).

${ }^{76}$ E.g., Abrams, supra note 43, at 1640 (concentrating on the pharmaceutical industry); Kesselheim, supra note 73, at 1855 (same); Rosemarie Ham Ziedonis, Don't Fence Me in: Fragmented Markets for Technology and the Patent Acquisition Strategies of Firms, 50 MGMT. SCI. 804, 804 (2004) (semiconductor industry); Bessen \& Hunt, supra note 73, at 157 (software industry).

${ }^{77}$ MERGES, supra note 30, at 2 (referring to balancing the costs and benefits of intellectual property as "impossibly complex"); Abrams, supra note 43, at 1641 ("Understanding the incentive effects of patent protection is a core issue in intellectual property scholarship, about which almost nothing is currently known.”); Burk \& Lemley, 
The inability of existing analysis to resolve the relationship between intellectual property law and innovation is an almost necessary consequence of using conventional law and economics approaches to try to evaluate this interaction directly. Because the relationship between innovation and law is so complex and contextual, it is impossible to take all pertinent factors into account or to convey lessons from one situation and time to another. ${ }^{78}$ The approach developed here provides an alternate perspective to better investigate this long considered problem, developing different means to parse the seemingly insurmountable challenge of the complexity of the real world interaction between innovation and intellectual property law. Where most prior law and economics efforts take either a top-down approach to measuring social welfare or a bottom-up approach to sum private preferences, proxy signals provide a third way to conduct law and economics analysis.

The proxy signal approach identifies states whose preferences are expected to structurally mirror the desired relationship between the beneficial incentives and exclusionary costs of patent law globally. These preferences are based on private and market information concerning the actual relationship between patent protection and innovation, information that cannot usually be captured. By aggregating the sum of private knowledge concerning this relationship and locating proxy signals concerning optimal trade-offs in patent law, this approach can move us closer than prior methods to maximizing global net incentives to innovate. Rather than succumbing to the impediment in much economic analysis of trying to fit an economic model to the complexity of the real world, the proxy technique takes advantage of real world variation as a signaling tool. The following sections present the proxy signal framework for using country preferences to signal globally favorable intellectual property incentive regimes.

supra note 19, at 1581 ("Rather than resolve the debate over how well the patent system works, ... [legal and economic scholarship] has painted a more complex picture."); Roberto Mazzoleni \& Richard R. Nelson, Economic Theories About the Benefits and Costs of Patents, 32 J. ECON. IssuES 1031, 1051 (1998) (conducting a literature review of patent analysis covering forty years and concluding, "[o]ur lack of knowledge here clearly limits our ability to analyze intelligently the current pressing issues of patent reform."); George L. Priest, What Economists Can Tell Lawyers About Intellectual Property: Comment on Cheung, 8 RES. L. \& ECON. 19, 21 (1986) ("[I]n the current state of knowledge, economists know almost nothing about the effect on social welfare of the patent system or of other systems of intellectual property."); FRITZ MACHLUP, STUDY OF THE U.S. SENATE SubcommitTEe On PATENTS, TRADEMARKS, \& COPYRIGHTS: AN ECONOMIC REVIEW OF THE PATENT SYSTEM 79 (Comm. Print 1958) ("No economist, on the basis of present knowledge, could possibly state with certainty that the patent system, as it now operates, confers a net benefit or a net loss upon society.”).

78 See MACHLUP, supra note 77, at 79-80 ("The best [any economist studying the patent system] can do is to state assumptions and make guesses about the extent to which reality corresponds to these assumptions."). 


\section{Country Political Economy of Intellectual Property as a Proxy}

Decades of effort indicate that we cannot directly solve how to balance the trade-off between the incentive benefits and exclusivity costs of patent law. We may, however, be able to use proxy signals as an indirect method to decipher information about where the net incentives sweet spot lies. If it is possible to identify proxies that inherently (1) face similar trade-offs to the balance that would optimize net incentives for innovation globally, and (2) possess superior information concerning this relationship, then such proxies could signal optimal levels of patent protection. In the international intellectual property context, certain countries may be able to serve in this role.

If we assume a well-functioning political environment, for initial purposes, country preferences for intellectual property rights should present an aggregation of private information and preferences for intellectual property protection. ${ }^{79}$ Country-level preferences should aggregate both domestic private industry preferences and domestic consumer interests. ${ }^{80}$ This preference aggregation will integrate both the domestic production interests and the domestic consumption interests in innovation. To the extent the political process functions well (admittedly a big "if," discussed later in the paper), country preferences for intellectual property rights would thus collect vast private information concerning both the benefits from the incentives of patent protection and the costs of exclusivity produced by patent rights. ${ }^{81}$ These are precisely the factors that need to be balanced to determine how to optimize innovation and intellectual property rights, information that is not generally available to public policy makers. 82

Domestic production interests have both a domestic and a foreign component, as domestic industry can profit both from the sale of intellectual property products at home and their sale abroad. Domestic consumption interests similarly have both domestic and foreign components. The domestic consumption component reflects the exclusivity costs borne by domestic consumers due to intellectual property rights held by domestic producers, while the foreign component reflects the exclusivity costs borne by domestic

${ }^{79}$ See Brewster, supra note 28 , at 4-5 (suggesting that in the context of the TRIPS agreement, states' preferences reflect their combined institutions); Drahos, supra note 7, at 771-72 (describing how the intellectual property rights afforded by TRIPS were significantly shaped by private sector preferences and interests); Grossman \& Lai, supra note 9, at 1651 (concluding that a state's optimal level of intellectual property protection is determined by aggregating the patent protection preferences of private firms).

${ }^{80}$ See Scotchmer, supra note 12, at 416 ("[T]he domestic interests of countries' innovators must be balanced against the interests of domestic consumers . . ..").

${ }^{81}$ See SELL, supra note 7, at 46-51 (noting the private sector's "expertise and control over information" relating to innovation and the functioning of intellectual property rights).

82 See Drahos, supra note 7 , at 772 (discussing how private industries often hold superior information concerning intellectual property rights than public entities, which often lack data). 
consumers due to intellectual property rights held by foreign producers. These relationships are displayed in Table 1.

Table 1: Country-Level Intellectual Property Interests

\begin{tabular}{|l|l|l|}
\hline & $\begin{array}{l}\text { Benefits of Incentives: } \\
\text { Producer Interests }\end{array}$ & $\begin{array}{l}\text { Exclusivity Costs: } \\
\text { Consumer Interests }\end{array}$ \\
\hline $\begin{array}{l}\text { Domestic } \\
\text { Component }\end{array}$ & $\begin{array}{l}\text { Profit from IP Rights in } \\
\text { Domestic Market }\end{array}$ & $\begin{array}{l}\text { Cost of IP Rights held by } \\
\text { Domestic Producers }\end{array}$ \\
\hline $\begin{array}{l}\text { Foreign } \\
\text { Component }\end{array}$ & $\begin{array}{l}\text { Profit from IP Rights in } \\
\text { Foreign Markets }\end{array}$ & $\begin{array}{l}\text { Cost of IP Rights held by } \\
\text { Foreign Producers }\end{array}$ \\
\hline
\end{tabular}

From the perspective of country preferences for global intellectual property rights, the domestic production and domestic consumption components identified above will cancel each other out, as the amount that domestic innovators profit off of intellectual property rights in the domestic market is the same as the amount that domestic consumers pay for intellectual property rights in the domestic market. Consequently, the net interest that a country presents in the international context will be determined by the relationship between the foreign component of domestic intellectual property production interests (i.e., how much domestic producers profit from intellectual property rights in foreign markets) and the foreign component of domestic intellectual property consumption interests (i.e., how much domestic consumers pay due to intellectual property rights held by foreign producers). Country-level preferences and advocacy for intellectual property law in the international context should therefore reflect the relationship between the value of intellectual property products produced by domestic innovators to external markets versus the value of intellectual property products consumed by domestic consumers from external markets. This relationship between the value of intellectual property production versus the value of intellectual property consumption is equivalent to the relationship between the incentive benefits of intellectual property protection and the exclusivity costs of protection, precisely the relation we need to evaluate to determine where the optimal level of intellectual property protection lies. ${ }^{83}$

These effects can be understood graphically. Figure 2 adds a pair of hypothetical country preference functions to the original net incentives function of Figure 1. Country $A$ represents a country that is a heavy net producer of innovation products. That is, the value of intellectual property products

${ }^{83}$ See Grossman \& Lai, supra note 9, at 1646 (identifying the relationship between the value of intellectual property production and the value of intellectual property consumption as the dynamic that drives preferences for stronger or weaker patent protection); Maskus, supra note 18, at 2221-22 (noting the differential between production and consumption interests in intellectual property as the driving force of country intellectual property preferences). 
produced to foreign markets by Country $A$ exceeds the value of intellectual property products from abroad that are consumed by Country $A$. Because Country $A$ is a net producer of intellectual property products, it can benefit from a stronger global patent rights regime to extract large monopoly profits, regardless of whether such patent protection levels increase net incentives to innovate globally. The generally technologically advanced Country A's of the world face greater incentive benefits from stronger patent protection, and fewer exclusivity costs due to protection, than the point of optimal balance. This leads such countries, as a natural side-effect of their innovation trade imbalance, to advocate for stronger patent protection than will optimize net incentives globally. ${ }^{84}$

Figure 2: Country Preferences for Intellectual Property Protection

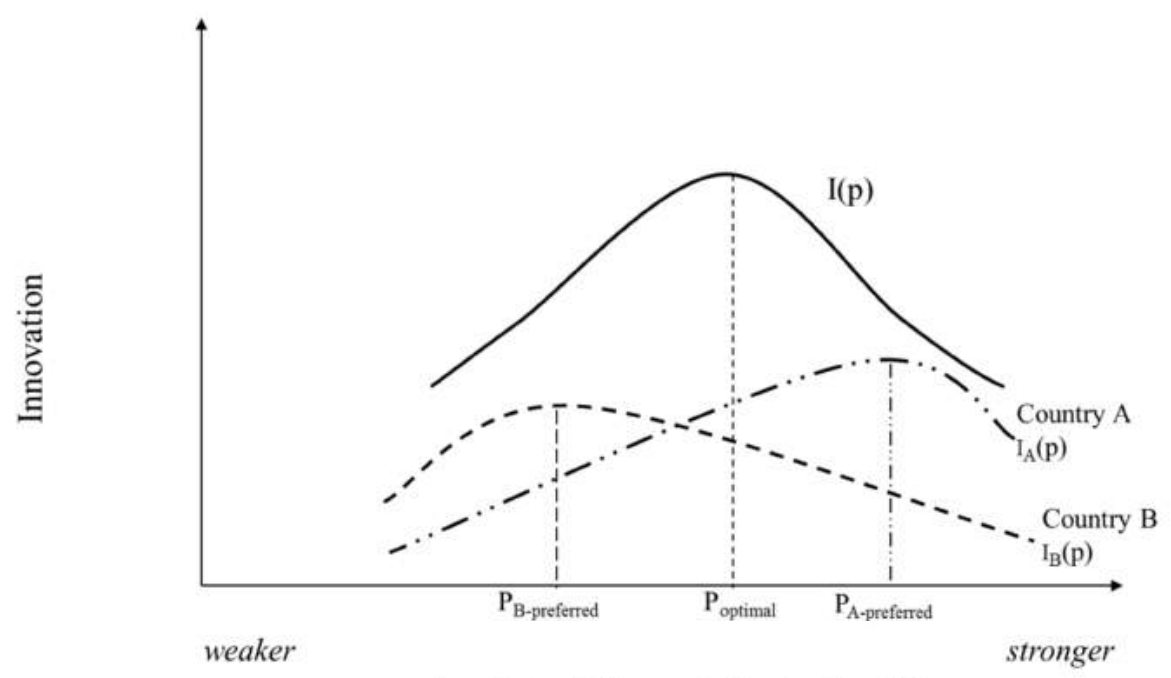

Intellectual Property Protection (P)

Conversely, Country $B$ represents a country that is a net consumer of innovation products. Here, the value of intellectual property products consumed domestically from foreign producers exceeds the value of intellectual property products produced domestically for foreign consumers. The Country $B$ 's of the world face relatively fewer incentive benefits and higher exclusivity costs than the point of optimal balance, and will consequently favor weaker patent protection than the level that would optimize aggregate global incentives. ${ }^{85}$

${ }^{84}$ See Scotchmer, supra note 12, at 417 (using economic modeling to demonstrate that "more innovative countries will favor more extensive intellectual property rights than less innovative countries.").

${ }^{85}$ See Salama \& Benoliel, supra note 9, at 635-37 (explaining that the lack of innovation in the Brazilian pharmaceutical sector, combined with the great benefit of cheap 
Country advocacy for intellectual property law will be self-interested, seeking to maximize the value of intellectual property rights for the particular country. ${ }^{86}$ Each country will advocate, in international negotiations and other fora, for a level of patent protection consistent with its own best interests. ${ }^{87}$ If, for example, strengthening patent protection would allow a heavy net-producer country to profit by generating greater foreign production gains from propertization than it suffers domestic consumer losses, such a country will favor stronger patent protection, regardless of whether greater propertization will expand or reduce aggregate global incentives to innovate. For these reasons, country advocacy concerning patent law generally will not provide a useful signal concerning the optimal level of patent protection for society globally.

Some countries, however, may face domestic intellectual property tradeoffs that more closely mirror a balance between the production and consumption interests in innovation. Countries that consume about the same value of innovation from foreign producers as the value of innovation that domestic producers export to foreign consumers will be in this position. Such countries happen to internally balance the production-versus-consumption interests in intellectual property rights, and consequently will desire to balance the incentive-versus-exclusivity trade-offs in intellectual property law. This is the same balance that is necessary to optimize cumulative net incentives to innovate. Country $C$ in Figure 3 provides an example of a country that faces relatively balanced incentive-versus-exclusivity trade-offs from intellectual property protection. These structural trade characteristics will lead Country $C$ to prefer more optimal levels of patent protection from a net incentives perspective than either Country $A$ or Country $B$. This desire manifests not because Country $C$ is altruistic, but as a side-effect of Country $C$ 's particular innovation tradeoffs in the real world market.

pharmaceuticals for consumers, produces political pressure to aggressively challenge pharmaceutical patent protection from a domestic perspective).

${ }^{86}$ SCOTCHMER, supra note 23, at 332-33; Maskus, supra note 18, at 2222.

87 The impact of social and public choice effects, and of psychological and behavioral heuristics, on whether countries actually advocate for their own best interests are discussed infra in Part III.B.2. 
Figure 3: Country Preference and Innovation

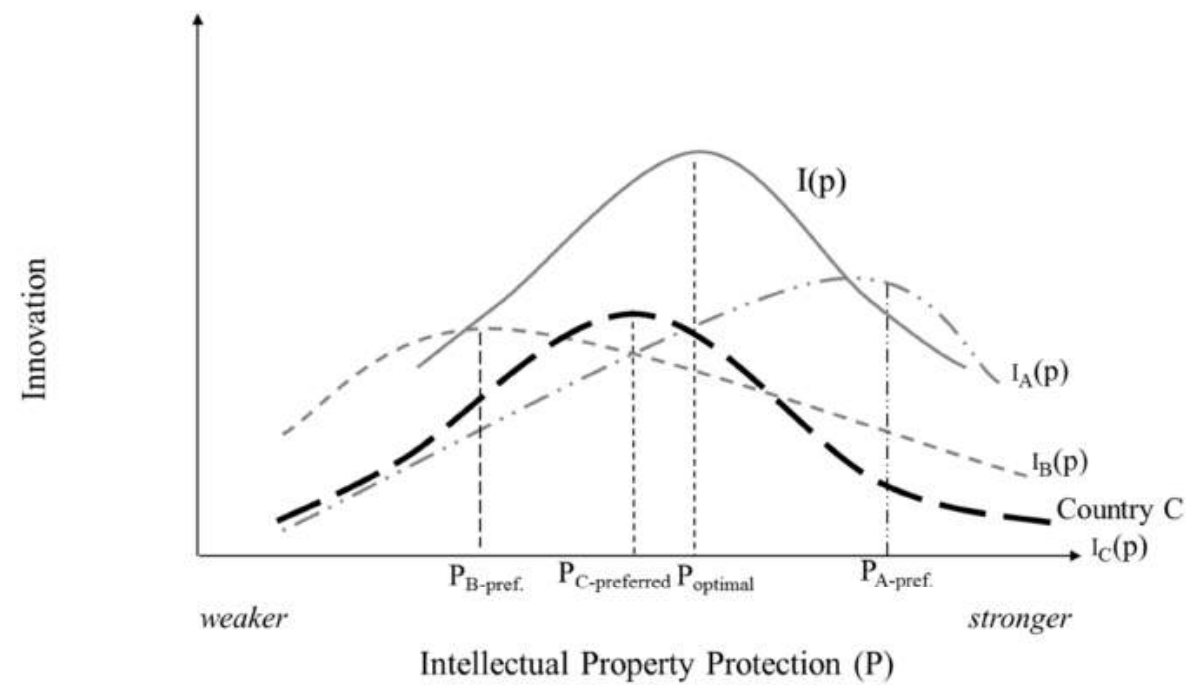

Figure 3 reveals that the size of a country's innovation market, whether production or consumption, is irrelevant to whether the country will tend to advocate for or against a socially preferable level of intellectual property protection. ${ }^{88}$ Rather, what matters is the relationship between the value of intellectual property products produced for foreign markets versus the value domestic consumers pay due to intellectual property rights held by foreigners. ${ }^{89}$ As long as these two quantities are relatively balanced, a country will tend to naturally desire a balancing of the incentives and costs of patent protection, and consequently a globally beneficial level of patent rights. This will occur regardless of whether a country is a relatively small or relatively large producer or consumer of intellectual property products.

Identifying countries that balance the production and consumption interests of intellectual property protection can yield powerful results. Even though we

88 Compare Grossman \& Lai, supra note 9, at 1646 (concluding based on an economic model that country size does not have a per se effect upon preferences with intellectual property rights, but that " $[\mathrm{t}]$ he role of market size in generating different incentives for the governments has to do... with the relative effectiveness of the countries' policy instruments"), with Scotchmer, supra note 12, at 417 (concluding based on an economic model that "small countries will favor more extensive intellectual property rights than large countries"). The difference between the analysis here and Scotchmer's work is that Scotchmer holds "innovativeness" across large and small countries constant in reaching her conclusion, while the analysis here identifies particular countries that balance their production and consumption interests in intellectual property (i.e., it does not hold innovativeness constant across countries, but searches for countries that match the value of innovativeness production to the value of innovativeness consumption).

${ }^{89}$ Scotchmer, supra note 12 , at 416. 
may not be able to directly identify the optimal level of intellectual property protection to maximize net incentives to innovate, we may instead be able to identify a proxy that mirrors the desired relationship to balance incentives and exclusivity. Because the identified proxy will tend to desire the same level of propertization for self-interested reasons as is desired globally to optimize net incentives to innovate overall, proxy advocacy can produce valuable patent law signals.

\section{E. Country Versus Industry Proxy Signals}

In prior work that developed the proxy signal concept for domestic patent law, the proposed proxy signals were based on identifying particular industry preferences, not country preferences. ${ }^{90}$ Such industries were selected based on a number of technology, industry, and market characteristics in an effort to identify industries that would inherently desire a balance in the incentive benefits and exclusivity costs of patent law. ${ }^{91}$ These industries would then be expected to advocate for domestic patent law that properly balanced the tradeoff between incentives and limitations on access. ${ }^{92}$

The level of patent protection that is beneficial for a particular industry at the domestic level, however, does not signal the international level of patent protection that would optimize net incentives to innovate globally. Industries do not function well as proxies for global patent objectives because unaccounted for cross-border trade effects create innovation externalities. An industry that profits heavily from intellectual property rights abroad, for example, may not face any internal costs from such external intellectual property protection. Country proxy signals, however, can serve the net incentives goal. To the extent countries accurately agglomerate private industry and private consumer interests, they reflect the relationship between the production and consumption of innovation within that country.

Country-level proxy analysis is also more practical in the international patent law context because countries are the traditional intellectual property actors internationally. An additional potentially valuable advantage of countries as proxies is that countries can aggregate a far broader spectrum of information than a single industry. Countries admittedly, however, will not be perfect proxies. Countries and industries both face agency concerns in selecting preferences, though the challenges for countries may be greater. Agency problems arise for industries as proxies because individuals within firms may act in their own best interests, rather than in the firm's best interests. ${ }^{93}$ Using

${ }^{90}$ Mandel, supra note 20 , at 1.

91 Id. at 33-40.

92 Id. at 34 .

${ }^{93}$ See V.V. Chari, Mikhail Golosov \& Aleh Tsyvinski, Prizes and Patents: Using Market Signals to Provide Incentives for Innovations, 147 J. ECON. THEORY 781, 783 (2012) (describing hidden buybacks in the patent system as a way in which the preferences of individuals in an organization can drive the actions of a firm); Daniel J.H. Greenwood, 
countries as proxies raises not only these concerns, ${ }^{94}$ but also a host of public choice and capture challenges ${ }^{95}$ that may lead country advocacy concerning international patent law not to accurately reflect the aggregation of domestic production and domestic consumption interests in patent protection. ${ }^{96}$ Further, countries may identify flexibilities under international law that allow them to treat different industries within the country differently, enabling such countries to favor patent production interests in certain industries that are active innovators within the country while favoring patent consumption interests in other industries where most innovation is imported from abroad. ${ }^{97}$

Using country preferences as proxy signals to improve global incentives to innovate is thus a promising avenue, but there are significant challenges. The following Part provides greater detail concerning how proxy signal analysis can be applied and explains how questions concerning the use of country advocacy as a proxy signal can be ameliorated.

Enronitis: Why Good Corporations Go Bad, 2004 ColuM. Bus. L. REV. 773, 775-77 (discussing the paradoxical nature of corporate law and the negative consequences when individuals go against the dictate of corporate law to set aside their best interest in favor of the firm); Brayden G. King, Teppo Felin \& David A. Whetten, Perspective-Finding the Organization in Organizational Theory: A Meta-Theory of the Organization as a Social Actor, 21 ORG. SCI. 290, 292-93 (2010) (using organizational theory to characterize organizations as individuals whose interests drive organizational level choices). But $c f$. Roland Bénabou \& Jean Tirole, Individual and Corporate Social Responsibility, 77 ECONOMICA 1, 2-3 (2010) (arguing that most people, even in a corporate capacity, are driven by genuine altruism and the desire to do good).

94 ANTHONY DOWNS, AN ECONOMIC THEORY OF DEMOCRACY 28 (1957) (arguing that politicians "act solely in order to attain the income, prestige, and power which come from being in office"); Ozan O. Varol, The Democratic Coup d'Etat, 53 HaRV. INT'L L.J. 291, 309-12 (2012) (discussing the body of literature supporting the theory that politicians largely act in their own self-interest).

95 See, e.g., SteVEn P. Croley, Regulation and Public Interests: The Possibility OF GOOD REGUlATORY GOVERNMENT 298 (2008) (discussing the problems of public choice and regulatory capture); Downs, supra note 94, at 28 (identifying certain public choice issues with respect to political representation and politician's interests); Robert W. McGee, Legal Ethics, Business Ethics and International Trade: Some Neglected Issues, 10 CARDOZO J. INT'L \& COMP. L. 109, 115-17, 125-26, 194 (2002) (discussing various manifestations of public choice problems).

96 Juan C. Ginarte \& Walter G. Park, Determinants of Patent Rights: A Cross-National Study, 26 RES. POL'Y 283, 290 (1997) (indicating that countries do not always act in their own best interests due to particular trade or specific industry interests); Phillip McCalman, National Patents, Innovation and International Agreements, 11 J. INT'L TRADE \& ECON. DEV. 1, 3-4 (2002) (examining the presence of externalities produced by patent agreements that may lead countries not to act in their own best interests); Stephen Yelderman, International Cooperation and the Patent-Antitrust Intersection, 19 TEX. INTELL. PROP. L.J. 193, 211-12 (2011) (citing the factors in international coordinated patent policy in which nations might opt for patent protection even when free riding is in their best interest).

97 See, e.g., Salama \& Benoliel, supra note 9, at 637 (discussing Brazil's use of TRIPS flexibilities to apply differing levels of patent protection to pharmaceuticals versus other technologies). 


\section{APPlying InTERnAtional PROXY Signals}

Applying country advocacy as a proxy signal in real world context presents a number of challenges and questions. Utilizing existing international trade data, the first section of this Part demonstrates in greater detail how country proxy signaling could work, and discusses further data that could be developed. The latter sections flesh out a number of details and respond to likely questions about the proxy approach, including consideration of how proxy analysis can function dynamically, how to measure country preferences, and the potential to differentiate patent law across different industries.

\section{A. Measuring Intellectual Property Production and Consumption}

The proxy methodology developed here relies on comparing the value of patent protection derived by intellectual property producers within a given country from foreign markets against the cost of patent protection incurred by intellectual property consumers within the same country due to foreign intellectual property producers. Though these valuations cannot be measured exactly, rough approximation can yield valuable information that has never been captured or utilized before.

The United Nations Commodity Trade Statistics (Comtrade) database is the leading source of data on international imports and exports. ${ }^{98}$ Comtrade provides commodity trade flow data for over 140 countries in the United Nations, including both import cost and export valuation at the customs frontier of the given country. ${ }^{99}$ The commodities and export/import data are divided by Standard International Trade Classification (SITC) code, allowing

\footnotetext{
98 Guillaume Gaulier \& Soledad Zignago, BACI: International Trade Database at the Product-Level, the 1994-2007 Version 7 (Centre D'Etudes Prospective et D'Informations Internationales, Working Paper No. 2010-23, 2010), available at http://papers.ssrn.com/abstract=1994500 (referring to Comtrade as "the most comprehensive database on world trade"); Sunil Mani, Exports of High Technology Products from Developing Countries: Is it Real or Statistical Artifact?, at 16 n.4 (United Nations University Intech Institute for New Technologies, Discussion Paper Series No. 2001-1, 2000) (describing Comtrade as "by far the most comprehensive source of trade statistics").

${ }^{99}$ James E. Anderson \& Eric van Wincoop, Trade Costs 6 (Nat'l Bureau of Econ. Research, Working Paper No. 10480, May 2004); U.N. Comtrade Database, UnITED NATIONS, http://comtrade.un.org/ (last visited Oct. 7, 2014), archived at http://perma.cc/WAX8-A9BC. Comtrade provides both import and export valuation data, and "re-import" and "re-export" valuation data where such data has been provided by a country. Id. Re-imports refers to situations where a country exports a product, and then imports the same particular product, for example as a component of a now manufactured machine. Id. Re-exports refer to the converse: where a country imports a foreign good and then exports it. Id. For purposes of analysis here, re-imports are incorporated into a country's imports and re-exports are incorporated into a country's exports, as this treatment aligns the country's interest in paying for or profiting from the product with the direction of the incentives that are the target of proxy analysis.
} 
differentiation of trade flow information by country across thousands of different product categories.

Gross import and export data is not useful for intellectual property law proxy analysis. What we need for proxy signals for international intellectual property law is not data on all imports and exports, but information on trade flow value that derives from intellectual property rights protection. A commonly used surrogate for this innovation value is data on trade flow in products with the highest research and development intensity. ${ }^{100}$ Research and development intensity measures the proportion of a product's value that derives from research and development activity, and is calculated by dividing the research and development expense to produce a given product by the product's total sales value. ${ }^{101}$ Research and development intensity thus provides a useful measure for identifying those products that derive the highest proportion of their value from innovation activity. ${ }^{102}$

Using research and development intensity to identify products that derive the highest proportion of their value from innovation is not a perfect surrogate for products that derive the highest proportion of their value from patent protection. This is both because innovation value can be secured through means other than patent protection, and because there may be product value created by non-patented aspects of a high research intensity product's development. ${ }^{103}$ For the purposes of introducing proxy analysis, however, the research and development intensity measure should do a reasonable job of identifying those products that benefit the most in value from patent protection, ${ }^{104}$ and therefore are the most important products for trade flow purposes for proxy signal

100 Benoît Godin, The Obsession for Competitiveness and its Impact on Statistics: The Construction of High-Technology Indicators, 33 RES. POL'Y 1217, 1219-21 (2004) (describing the development of the use of research and development intensity as a surrogate for data on high-technology trade); Michael J. Ferrantino, Robert B. Koopman, Zhi Wang \& Falan Yinug, The Nature of US-China Trade in Advanced Technology Products, 52 CoMP. ECON. STUD. 207, 210 (2010) (indicating the use of research and development as a proxy for the technology in a product).

${ }^{101}$ Godin, supra note 100 , at 1218 (defining this research and development indicator ratio).

${ }^{102}$ Mani, supra note 98, at 29 (utilizing the OECD definition of high-tech (high research intensity) products for Comtrade data and stating that such products involve the greatest product innovation); Louis Raymond \& Josée St-Pierre, $R \& D$ as a Determinant of Innovation in Manufacturing SMEs: An Attempt at Empirical Clarification, 30 TECHNOVATION 48, 49 (2010) (noting that product innovation plays the greatest role in high research intensity sectors).

103 See Wesley M. Cohen, Richard R. Nelson \& John P. Walsh, Protecting Their Intellectual Assets: Appropriability Conditions and Why U.S. Manufacturing Firms Patent (or Not) 1 (Nat'l Bureau of Econ. Research, Working Paper No. 7552, 2000) (presenting survey data on why firms in different industries patent and how they derive value from their intellectual creations).

${ }^{104}$ Mani, supra note 98, at 9 (using research and development intensity to measure innovation value of exports in this regard). 
analysis. As discussed below, this data could be further refined for future analyses.

The Organisation for Economic Co-operation and Development (OECD) has identified the sixty-two product categories out of over 3,000 SITC product categories that display very high research intensity ratios. ${ }^{105}$ These high research intensity products range from semiconductors to optical equipment to pharmaceuticals. ${ }^{106}$

In order to provide a proof-of-concept test for proxy signal analysis, I selected eleven countries at different stages of technological development and collected Comtrade import and export data for these countries for all sixty-two high research intensity data categories for 2012, the latest full year of available data. The countries selected were: Brazil, China, Germany, India, Indonesia, Japan, Malaysia, Mexico, South Africa, South Korea, Spain, Ukraine, and the United States. ${ }^{107}$ The countries purposely include a range of developing, BRIC, and highly technologically-advanced economies.

The results of the Comtrade high research intensity product analysis are reported in Table 2. The first two columns for each country display that country's total high-intensity product exports and imports for 2012, in millions of dollars. Column (c) is the difference between Column (a) and Column (b), essentially a country's trade surplus (if positive) or deficit (if negative) in high research intensity products for 2012. Absolute trade differentials are not very useful for proxy signal analysis. A country could have a very low trade differential simply because it does not import or export many high research intensity products. Such a country, however, likely would not care significantly about the level of patent protection, and therefore would not serve as a useful proxy. More important than absolute trade differential statistics for identifying countries for proxy analysis is the ratio of a country's high research intensity trade differential relative to its total trade volume in such products. This statistic is reported in Column (d). Countries with a low trade differential ratio will tend to have reasonably balanced interests in the import and export of high research intensity products, precisely the relationship desired for proxy signal analysis.

105 Anderson \& van Wincoop, supra note 99, at 6; EUROSTAT, High-TECH PrOduCTS (2014), http://epp.eurostat.ec.europa.eu/cache/ITY_SDDS/Annexes/htec_esms_an4.pdf; U.N. Comtrade Database, supra note 99. Standard International Trade Classification Rev. 3, which was used for this paper's analysis, has 3,118 basic headings and subheadings, which are organized into 261 groups, 67 divisions and 10 sections. Id.

${ }^{106}$ U.N. Comtrade Database, supra note 99; Mani, supra note 98, at 15 n.3 (citing some of the products U.N. Comtrade covers).

${ }^{107}$ Kenya and Nigeria were originally included in the list of countries, but had to be removed as data had been reported for only a small portion of the product categories for each country. 
Table 2. High Research Intensity Imports and Exports in Millions of U.S Dollars (2012)108

\begin{tabular}{|l|c|c|c|c|}
\hline & $\begin{array}{c}\text { High } \\
\text { Research } \\
\text { Intensity } \\
\text { Exports } \\
\text { (a) }\end{array}$ & $\begin{array}{c}\text { High } \\
\text { Research } \\
\text { Intensity } \\
\text { Imports } \\
\text { (b) }\end{array}$ & $\begin{array}{c}\text { High } \\
\text { Research } \\
\text { Intensity } \\
\text { Trade } \\
\text { Differential } \\
\text { (c) }\end{array}$ & $\begin{array}{c}\text { Differential } \\
\text { (Exports } \\
\text { Imports) } \\
\text { (d) }\end{array}$ \\
\hline Brazil & 9,778 & 35,418 & $-25,640$ & -0.5673 \\
\hline China & 610,352 & 610,248 & 104 & 0.0001 \\
\hline Germany & 201,334 & 163,282 & 38,052 & 0.1044 \\
\hline India & 11,792 & 34,146 & $-22,354$ & -0.4866 \\
\hline Indonesia & 7,727 & 26,543 & $-18,816$ & -0.5490 \\
\hline Japan & 139,590 & 129,364 & 10,226 & 0.0380 \\
\hline Malaysia & 64,958 & 56,756 & 8,201 & 0.0674 \\
\hline Mexico & 53,840 & 104,291 & $-50,451$ & -0.3190 \\
\hline South Africa & 2,375 & 11,208 & $-8,832$ & -0.6503 \\
\hline South Korea & 140,039 & 83,436 & 56,604 & 0.2533 \\
\hline Spain & 13,631 & 24,866 & $-11,235$ & -0.2918 \\
\hline Ukraine & 2,825 & 6,072 & $-3,247$ & -0.3649 \\
\hline USA & 310,933 & 396,591 & $-85,659$ & -0.1211 \\
\hline & & & & \\
\hline
\end{tabular}

As revealed in Table 2, of the eleven countries selected for analysis here, China, Japan, and Malaysia all display relatively balanced relationships between the value of high research intensity products exported and high research

108 U.N. Comtrade Database, supra note 99. 
intensity products imported. Such countries will tend to have relatively balanced interests between promoting the incentives of patent protection and guarding against the exclusionary costs that patent protection creates. Proxy analysis thus indicates that these countries, acting in their own best interests, should care very strongly about setting international patent protection at a level that will optimize global incentives to innovate.

The appearance of China on this list will undoubtedly surprise some, and could be due to some of the restrictions inherent in the current Comtrade data, which are discussed further below. ${ }^{109}$ That said, despite China's historic reputation as a reluctant supporter of intellectual property rights, China's economy has been shifting towards greater innovation, ${ }^{110}$ a shift reflected in the statistics reported in Table 2. As others have already noted, this shift towards greater innovation appears to be leading China to support stronger patent protection laws and enforcement than it had previously, ${ }^{111}$ precisely as the proxy approach would predict.

Other interesting results can be gleaned from the data reported in Table 2. For example, Brazil and Indonesia possess the two greatest high research intensity trade deficits of the eleven countries analyzed here. This indicates that such countries tend to pay substantial exclusionary costs due to patent protection, while garnering relatively few beneficial incentives. Consistent with this result, Brazil and Indonesia have generally favored weaker intellectual property rights laws. ${ }^{112}$

Though the Comtrade data is valuable for proxy signal analysis, more precise data could be developed. First, the Comtrade data is based on import and export value at the customs frontier, but does not identify the nationality of the entity that derives value from such trades. Where a domestic firm exports intellectual property products from a foreign country in which it operates, such value will appear in the Comtrade database as attached to the foreign country even though the reality is that the intellectual property value is spread across both countries. In many cases, publically available data concerning firm ownership and operation could be used to make such calculations more precisely.

${ }^{109}$ In addition, the reliability of certain of China's economic statistics has been questioned in other contexts. Derek Scissors, How to Make China More Honest, BACKGROUNDER, No. 2839, Sept. 4, 2013, at 1, available at http://thf_media.s3.amazonaws.com/2013/pdf/bg2839.pdf. As discussed below, because all imports and exports require two party interaction, it would be highly feasible to introduce an audit mechanism into proxy signal analysis were this framework to be implemented. See infra Part III.B.1.

${ }^{110}$ See Peter K. Yu, The Global Intellectual Property Order and its Undetermined Future, 2009 WIPO J. 1, 12.

${ }^{111}$ See id. at 12-13; Jerome H. Reichman, Intellectual Property in the Twenty-First Century: Will the Developing Countries Lead or Follow?, 46 Hous. L. REV. 1115, 1124 (2009); Yu, Cultural Relics, supra note 1, at 504.

112 See Bird, supra note 14, at 322-29; Bird \& Cahoy, supra note 1, at 403; Stiglitz, supra note 14, at 1694; Yu, supra note 110, at 13. 
Second, as noted above, there is not a perfect correlation between high research intensity products (the data that Comtrade provides) and products that derive the greatest value from innovation (the data desired for proxy signal analysis). ${ }^{113}$ In order to conduct more precise analysis, the OECD hightechnology product categories could be differentiated based on the proportion of a product's value that derives from patent protection, and the product categories could be weighted according to these proportions. Summing high-technology import and export valuations in this manner would provide a more accurate picture of which countries face the closest balance between the net amount that they profit from patent protection versus the net cost incurred as a result of protection.

\section{B. Proxy Signal Challenges}

Though the Comtrade data and analysis represents a good start, application of proxy signal analysis to the actual political economy of international intellectual property presents a number of hurdles. This section fleshes out several details concerning how proxy analysis could function in practice and responds to likely questions about the new approach. These sections explain how proxy analysis can function dynamically to respond to the continual evolution in intellectual property markets, how to address country proxy signal measurement and selection challenges, the potential to differentiate patent law across different industries under a proxy signal paradigm, and other matters.

\section{Dynamic Proxy Signals}

The relationship between the production and consumption of intellectual property goods and services within any given state will continually evolve as a result of technological innovation and market forces. Proxy analysis indicates that as countries become greater net producers or heavier net consumers of intellectual property products, their preferences and advocacy for given levels of intellectual property protection will evolve concurrently. Historical evidence supports this inference. For example, though the United Kingdom is currently a strong proponent of patent protection, for a significant part of the twentieth century the United Kingdom excluded chemical products from patent protection or enabled compulsory licensing for them in an effort to protect a domestic chemical industry that lagged behind foreign producers of chemical product innovation. ${ }^{14}$ Similarly, during most of the nineteenth century, Japan was a well-known intellectual property pirate and the United States a well-known copyright pirate, each at times when they were net importers of intellectual

113 See Godin, supra note 100, at 1218-21.

${ }^{114}$ George, supra note 16 , at 11 . 
property products developed abroad. ${ }^{115}$ An era of rapid technological development over the past several decades has led South Korea to shift advocacy positions from being a weak enforcer of intellectual property rights to a proponent of stronger protection. ${ }^{116}$ For similar reasons, and as partially discussed above, while both China and India have generally opposed strengthening intellectual property rights, each economy is now witnessing innovative sectors emerge. ${ }^{117}$ This shift towards greater innovation production appears to be leading China and India to moderate their positions on patent protection, at least in certain regards. ${ }^{118}$

As the relationship between the production of intellectual property products to foreign markets and consumption from foreign markets within a country changes, the country's significance and utility as a proxy signal will change as well. A change in the relationship between the production and consumption of intellectual property products within a country will cause the country's preferences for a given level of patent protection, and the country's advocacy in international dialogue, to evolve. As a country moves closer towards a balance between the production and consumption of intellectual property products, it will become a more accurate proxy signal; if the relationship between production and consumption becomes less equal, the country will be less useful as a proxy signal.

115 William W. Fisher III, Geistiges Eigentum-ein ausufernder Rechtsbereich: Die Geschichte des Ideenschutzes in den Vereinigten Staaten [The Growth of Intellectual Property: A History of the Ownership of Ideas in the United States], in EIGENTUM IM INTERNATIONALEN VeRGLeich 265, 265-91 (Hannes Siegrist \& David Sugarmann eds., 1999) (Ger.), available at http://cyber.law.harvard.edu/people/tfisher/iphistory.pdf; B. Zorina Khan \& Kenneth L. Sokoloff, History Lessons: The Early Development of Intellectual Property Institutions in the United States, 15 J. ECON. PERSP. 233, 234-37 (2001); Geoffrey R. Scott, A Comparative View of Copyright As Cultural Property in Japan and the United States, 20 TEMP. INT'L \& COMP. L.J. 283, 330 (2006). The United States did not join the Berne Convention, granting reciprocal copyright protection to nationals of other signatories, until 1989. Orrin G. Hatch, Better Late Than Never: Implementation of the 1886 Berne Convention, 22 CORNELl INT'L L.J. 171, 172-77 (1989); Jane C. Ginsburg, The U.S. Experience with Mandatory Copyright Formalities: A Love/Hate Relationship, 33 ColuM. J.L. \& ARTS 311, 315-18, 322-32 (2010).

${ }^{116}$ Ruth Taplin, Protect and Survive: Managing Intellectual Property in the Far EastThe Case of South Korea, KNOWLEDGELINK NEWSL. (Thomson Scientific), Nov. 2004, at 12; Sang-Hyun Song \& Seong-Ki Kim, The Impact of Multilateral Trade Negotiations on Intellectual Property Laws in Korea, 13 UCLA PAC. BASIN L.J. 118, 119-22 (1994).

${ }^{117} \mathrm{Yu}$, supra note 110, at 12; Roger Bate, India and the Drug Patent Wars, Health POLICY OUTLOOK, AM. ENTERPRISE INST. FOR PUB. POL'Y RES. 1 (Feb. 2007), available at http://www.aei.org/files/2007/02/07/20070207_200702HPOg.pdf.

${ }^{118} \mathrm{Yu}$, supra note 110, at 12-13; Reichman, supra note 111, at 1124; Yu, Middle Intellectual Property Powers, supra note 1, at 504. 
Proxy signal analysis can operate dynamically to continually respond to changing intellectual property activity and advocacy. ${ }^{119}$ By reexamining country production to foreign markets versus consumption from foreign markets on a regular basis, and regularly reevaluating the advocacy positions of any countries determined to present accurate incentive versus trade-off balances, proxy analysis can not only maintain a proper target for intellectual property rights, but also prevent countries from being able to game the system for their own self-interest.

So long as we are able to select accurate proxy countries, and move away from using them once they no longer offer appropriate interest balancing, then proxy country preferences will reflect the level of patent protection that optimizes net incentives to innovate globally. Further, because proxy signal analysis is based on identifying countries whose interests align with society's interest in optimizing incentives to innovate, there would be little reason for any selected country to try to strategically game its advocacy. Certainly, countries that do not present balanced production versus consumption trade-offs will try to argue that they do possess such balance and may try to massage their trade data to indicate greater balance than they actually have. As discussed above, however, we already have significant external information available concerning these relationships, and there are additional data sources that could be developed. In addition, because the relationship between a country's foreign production and imported consumption of innovation is represented in the export and import of intellectual property products, such data necessarily involves an external trading partner in each case, which can be used to verify the information. This relationship makes it reasonably feasible to set up an audit mechanism for trade data that could make it difficult for countries to be deceptive concerning their individual relationship between intellectual property imports and exports. Though the proxy signal methodology may not be simple, it is a far easier task to measure country-level import and export of intellectual property goods than it is to try to directly evaluate all of the incentive benefits and exclusivity costs produced by a given level of intellectual property protection.

\section{Measuring Country Preferences}

The proxy signals methodology relies on two streams of information: the relationship between the production and consumption of intellectual property products by country and country intellectual property rights preferences. Both types of information present challenges for measurement and evaluation. ${ }^{120}$ The former was discussed above, the latter is examined here.

119 Cf. Gregory N. Mandel, Regulating Emerging Technologies, 1 L. InNOVATION \& TECH. 75, 88-90 (2009) (discussing the need for emerging technology governance systems to be able to adapt dynamically).

120 See supra Part III.A. 
Proxy analysis relies on countries being able to accurately evaluate and advocate for an aggregation of their domestic production and consumption interests. Even in a well-functioning political environment, it is not realistic to expect that this process will function precisely. A variety of agency problems produced by special interest pressure and lobbying, agency capture, and other political failures can lead states not to act in their own best interests. ${ }^{121}$ For example, large firms may exercise their political strength to promote overlyprotectionist intellectual property regimes that protect established firms against small and start-up companies, even though such regimes may lead to less innovation overall. ${ }^{122}$ Similarly, in many contexts the diffuse consumer interest in weaker intellectual property rights may be overcome by the more concentrated production interest that industry may have in greater propertization. ${ }^{123}$ That said, intellectual property consumers and their advocates have demonstrated significant and increasing strength over the past decade and have mobilized collective-action efforts to push back against what has been viewed as untoward expansion of intellectual property rights. ${ }^{124}$ These initiatives have had a substantial effect in international intellectual property law, including revisions to TRIPS and the defeat of the Anti-Counterfeiting Trade Agreement (ACTA). ${ }^{125}$

In certain circumstances, even countries with well-functioning political systems may not accurately understand their own preferences or what legal rules will be in their own best interests. Robert Hudec provided one of the most in-depth studies of the effects of preferential trade policies on developing country economies under the General Agreement on Tariffs and Trade (GATT)

121 William N. Eskridge, Jr., Politics Without Romance: Implications of Public Choice Theory for Statutory Interpretation, 74 VA. L. REV. 275, 276, 309-14 (1988); Saul Levmore, From Cynicism to Positive Theory in Public Choice, 87 CORNELl L. REV. 375, 380-82 (2002); Herbert Hovenkamp, Legislation, Well-Being, and Public Choice, 57 U. CHI. L. REV. 63, 83 (1990).

122 Golden, supra note 65, at 545-46; Reichman, supra note 111, at 1121.

123 Mancur Olson, The Logic of Collective Action: Public Goods And the THEORY OF GROUPS 46-48, 165-67 (2d prtg. 1971); see LANDES \& POSNER, supra note 55, at 407 (discussing an "inherent asymmetry between the value that creators of intellectual property place on having property rights and the value that would-be copiers place on freedom to copy without having to obtain a license...."); Yochai Benkler, Through the Looking Glass: Alice and the Constitutional Foundations of the Public Domain, 66 LAW \& CONTEMP. PROBS. 173, 196 (2003) (asserting a "systematic imbalance" between the benefits provided by intellectual property law to well-defined interest holders versus the diffuse economic, social, political, and moral costs of intellectual property rights).

${ }^{124}$ Kapczynski, supra note 16 , at 825-39.

${ }^{125}$ Robert E. Thomas \& Cassandra Aceves, Coalition Formation and Battles to Effect Intellectual Property Policy Change in the Age of ACTA, AIA and the SHIELD Act, in THE CHANGING FACE OF US PATENT LAW AND ITS IMPACT ON BUSINESS STRATEGY 15, 35 (Daniel R. Cahoy \& Lynda J. Oswald eds., 2013); Kapczynski, supra note 16, at 836; Susan K. Sell, Revenge of the "Nerds": Collective Action Against Intellectual Property Maximalism in the Global Information Age, 15 INT'L STUD. REV. 67, 68, 80-81 (2013). 
in general. ${ }^{126}$ Hudec concludes that developing states' successful advocacy for preferential treatment actually disserved their economic interests. ${ }^{127}$ This occurred because states that received the greatest preferential treatment did not diversify their exports or create new trade. ${ }^{128}$ In other words, states' successful pursuit of preferential treatment achieved short-term benefits at the expense of long-term development. ${ }^{129}$ Developed countries can be subject to miscalculations concerning their own best interests as well. The bounded rationality of human decision-making, for example, means that even individuals seeking to act in a state's best interests still may not be able to do so. ${ }^{130}$

Despite these hurdles, proxy analysis can still yield highly valuable information. The question is not whether we can conduct proxy analysis precisely, but whether we can achieve a rough approximation that is beneficial relative to current methods for trying to balance the incentive-versus-exclusivity effects of intellectual property rights. Given that we currently lack any grounded model for directly measuring this relationship, ${ }^{131}$ this concern is quite feasible to overcome. Even with the limitations noted above, state actors commonly still act on the basis of substantial information about industry and consumer interests within their jurisdictions, information that generally is not captured when analyzing overall incentives for innovation. Providing a mechanism for capturing the pertinent content of that information means that proxy analysis along the lines discussed here can yield new and valuable information about optimizing global incentives to innovate.

Proxy signals can be further strengthened by integrating results across multiple countries. No individual country will present a perfect proxy and it is likely that any particular country's signal will not be precise. Multiple countries, however, are likely to present proxies that approximate the desired balance between production and consumption interests in intellectual property rights. By aggregating proxy signals across several countries that appear to present the strongest production-versus-consumption balances, we can reduce the likelihood that problematic political processes or misinformation from any single country is biasing the overall results. ${ }^{132}$ Aggregating multiple country preferences in this manner will reduce the unsystematic variation in proxy

126 See generally RoBert E. Hudec, DeVeloping Countries In the GATT LegAL SySTEM (Cambridge Univ. Press 2d ed. 2011) (1987); Jeffrey L. Dunoff, Hudec's Methodsand Ours, 20 MiNN. J. INT'L L. 437 (2011) (discussing Hudec's work).

127 J. Michael Finger, Introduction to HuDEC, supra note 126, at 16-17; Dunoff, supra note 126 , at 437 .

128 Dunoff, supra note 126 , at 454.

${ }^{129}$ Dunoff, supra note 126 , at 454.

${ }^{130}$ Camerer, supra note 74, at 14-16; Gregory N. Mandel, Patently Non-Obvious: Empirical Demonstration that the Hindsight Bias Renders Patent Decisions Irrational, 67 OHIO ST. L.J. 1391, 1414 (2006).

131 See supra Part II.C.

132 Jerry Brito, Hack, Mash \& Peer: Crowdsourcing Government Transparency, 9 Colum. SCI. \& TECH. L. REV. 119, 141-48 (2008) (describing the benefits of such "crowdsourcing" of information in a variety of contexts and industries). 
signals that may arise due to errors in the underlying data or in countries identifying their own true preferences.

In addition, as noted above, the proxy signal framework is based on a onedimensional representation of patent law strength even though actual patent law can be strengthened or weakened along multiple dimensions. ${ }^{133}$ Aggregating proxy signals across several countries will help ameliorate any distortion introduced by this simplification. Though the final calculation may not be perfect, it should be far superior and based on much greater information than any other methodology that is currently available for trying to optimally promote innovation through patent protection.

\section{Industry-Specific Patent Law}

An added benefit of proxy analysis is that it may provide a framework to develop industry-specific patent law. It is well-recognized that the optimal level of intellectual property protection varies for different industries. ${ }^{134}$ For example, the level of patent propertization that would balance the trade-off between incentives and exclusivity in the pharmaceutical sector is almost certainly different from the level of propertization that would balance trade-offs in the software industry. ${ }^{135}$

Domestic patent law, however, generally takes a one-size-fits-all approach to patent protection, ${ }^{136}$ and international law has followed suit. Prior to TRIPS, the most technologically advanced countries had already instituted largely uniform patent laws across various industries. The same patent law generally applies whether one seeks a patent on a better mousetrap, component of a cell phone, or new nanobiotechnological process. ${ }^{137}$ Many less developed countries, however, differentiated patent rights by industry prior to the promulgation of

133 See supra note 65 and accompanying text.

${ }^{134}$ BurK \& LEMLEY, supra note 19, at 167; Michael W. Carroll, One Size Does Not Fit All: A Framework for Tailoring Intellectual Property Rights, 70 OHIO ST. L.J. 1361, 1366, 1389, 1406 (2009); Glynn S. Lunney, Jr., Patent Law, the Federal Circuit, and the Supreme Court: A Quiet Revolution, 11 SuP. CT. ECON. REV. 1, 6 (2003).

135 BURK \& LEMLEY, supra note 19, at 32-33 (discussing how intellectual property law affects different industries in different manners, given the different characteristics and structure of varying industries).

${ }^{136}$ Mayo Collaborative Servs. v. Prometheus Labs., Inc., 132 S. Ct. 1289, 1293-94 (2012) (noting the uniformity of United States patent law decisions); Burk \& Lemley, supra note 19, at 1576-77; Clarisa Long, Our Uniform Patent System, FED. LAw., Feb. 2008, at 44, 47-49.

13735 U.S.C. $\$ 101$ (2012) (the United States' patent-eligible subject matter law); European Patent Convention art. 52, Nov. 29, 2000, available at http://documents.epo.org/projects/babylon/eponet.nsf/0/00E0CD7FD461C0D5C1257C0600 50C376/\$File/EPC_15th_edition_2013.pdf (the European Union's patent-eligible subject matter law). There are certain ways in which patent rights did and do vary by industry in the most technologically advanced countries, but most are relatively minor variations. See Carroll, supra note 134 , at 1390. 
TRIPS. ${ }^{138}$ India, Brazil, and additional countries, for example, excluded pharmaceutical products and processes from patent eligibility in the 1970s and 1980s. ${ }^{139}$

The TRIPS agreement is the leading international agreement on intellectual property rights, and it substantially reduced such industry differentiation in patent law. TRIPS mandates certain requirements for the intellectual property laws of the 160 states that are members of the World Trade Organization (WTO). ${ }^{140}$ TRIPS obliges WTO members to provide particular patent, copyright, trademark, and other intellectual property rights to nationals of other WTO members. ${ }^{141}$ In the patent context, TRIPS requires that member states grant patents on inventions, whether products or processes, in all "fields of technology," provided the inventions meet other patentability requirements. ${ }^{142}$ There are exceptions, notably for certain public interests. ${ }^{143}$ Though TRIPS technically, in general, only requires minimum levels of intellectual property protection, in practice it has been used by the most technologically advanced countries to press for stronger substantive intellectual property rights almost across the board. ${ }^{144}$

The TRIPS agreement has been criticized for promoting this one-size-fitsall approach to patent law. ${ }^{145}$ For example, contrary to the variation in patentability across industries that used to exist in India, Brazil, and other developing countries, TRIPS includes specific provisions requiring protection of pharmaceuticals, bioengineered microorganisms, and computer software. ${ }^{146}$

138 Bird \& Cahoy, supra note 1 , at 403.

${ }^{139}$ Salama \& Benoliel, supra note 9, at 639; Bird \& Cahoy, supra note 1, at 403, 415; DeSalvo, supra note 36, at 14.

${ }^{140}$ Agreement on Trade-Related Aspects of Intellectual Property Rights, Apr. 15, 1994, 33 I.L.M. 1197, 1869 U.N.T.S. 299; Drahos, supra note 7, at 788; Members and Observers, WORLD TRADE ORGANIZATION, http://www.wto.org/english/thewto_e/whatis_e/tif_e/ org6_e.htm, archived at http://www.perma.cc/FYQ5-KQZN (last visited September 18, 2014) (indicating that there are 160 members of the World Trade Organization as of June 26, 2014).

141 Agreement on Trade-Related Aspects of Intellectual Property Rights, art. 4, Apr. 15, 1994, 33 I.L.M. 1197, 1869 U.N.T.S. 299.

142 Id. art. 27.1.2.

${ }^{143}$ See id. art. 27 (providing exceptions from patentability for inventions which threaten the public interest, such as by threatening "human, animal or plant life or health," as well as for certain surgical methods and plant organisms).

$144 \mathrm{Yu}$, supra note 110, at 5; Anu Bradford, When the WTO Works, and How It Fails, 51

VA. J. INT'L L. 1, 19-20 (2010); Salama \& Benoliel, supra note 9, at 646.

${ }^{145}$ Land, supra note 2 , at 435-36.

146 Agreement on Trade-Related Aspects of Intellectual Property Rights, art. 10, 39, 33 I.L.M. 1197, 1869 U.N.T.S. 299; see also Park, supra note 9, at 764 (identifying industries offered patent protection by TRIPS and exploring the consequences on industry variation); Laurence R. Helfer, Regime Shifting: The TRIPs Agreement and New Dynamics of International Intellectual Property Lawmaking, 29 YALE J. INT'L L. 1, 2 (2004) (discussing the fundamental shift in the international trade and use of intellectual property instituted by TRIPS). 
Subsequent to joining TRIPS, most countries have instituted relatively uniform patent laws across technological fields and industries. ${ }^{147}$ The harmonization of patent law across various industries is a problem for trying to achieve optimal incentives to innovate.

The country proxy signal approach introduced here could be used to identify optimal patent propertization levels that vary by industry. Rather than searching for countries that balance the production-versus-consumption of patent rights across all intellectual property product exports and imports collectively, one instead could search for countries that balance production versus consumption interests in intellectual property products in a particular industry. Such countries would have self-interested incentives to prefer a level of patent protection that optimizes net incentives to innovate for that particular industry, in the same manner as described above across all industries. ${ }^{148}$ Industry level proxy signal analysis may be easier to achieve than the overall proxy approach because it is easier to compare production versus consumption in a single specific industry, rather than across all industries significantly affected by patent protection. For example, research and development intensity, product definitions and groupings, and the ability to measure trade data will all tend to be more consistent within a single industry than across multiple industries.

The existing United Nations Comtrade data makes it relatively straightforward to differentiate trade flow data by industry. Using SITC codes, Comtrade divides high-intensity research import and export trade data across nine sectors: Aerospace, Computers and Office Machines, Electronics and Telecommunications, Pharmacy, Scientific Instruments, Electronic Machinery, Non-Electronic Machinery, Chemistry, and Armament. ${ }^{149}$ I used the Comtrade database to analyze imports and exports in each of these sectors, similar to the analysis conducted above for all imports and exports combined. ${ }^{150}$ The results of this analysis are reported in the Article's Appendix for the three largest sectors based on international trade value (Electronics and Telecommunications, Computers and Office Machines, and Scientific Instruments), as well as for Pharmacy, given the particularly vociferous debates over international intellectual property law as it relates to pharmaceuticals. ${ }^{151}$

147 See Carolyn DeERe, The Implementation Game: The TRIPS AgreEMENT AND the Global Politics of Intellectual Property Reform IN Developing Countries 1 (2009); Bird \& Cahoy, supra note 1, at 404, 410; DeSalvo, supra note 36, at 14; Salama \& Benoliel, supra note 9 , at 640 . Brazil, in particular, has been partially successful in using certain exceptions to effectively limit patent protection for pharmaceuticals in certain regards. Bird \& Cahoy, supra note 1, at 406 ; DeSalvo, supra note 36 , at 15 ; Salama \& Benoliel, supra note 9, at 637.

148 See supra Part II.D.

149 U.N. Comtrade Database, supra note 99; Eurostat, High-Tech Products (2014), http://epp.eurostat.ec.europa.eu/cache/ITY_SDDS/Annexes/htec_esms_an4.pdf.

150 See supra Part III.A.

151 The trade values for high research intensity goods in Electronics and Telecommunications ( $\$ 721$ billion in exports and $\$ 847$ billion in imports across the 11 
The sector analysis reveals, unsurprisingly, that different countries should serve as intellectual property proxies for different sectors. For example, Germany, Japan, and Malaysia all display a relatively balanced trade flow in the Electronics and Telecommunications sector. ${ }^{152}$ It is likely, therefore, that such countries' intellectual property preferences in this sector would be to optimize overall incentives to innovate, as opposed to being biased strongly in the direction of either excessive exclusionary rights or freeing access to the point that it harms innovation. Were we to try to set intellectual property rights differently by sector, in an effort to optimize incentives to innovate in each sector, Germany, Japan, and Malaysia appear to be promising candidates for further study in electronics and telecommunications, at least from among the eleven countries studied here.

In other sectors, different countries are more promising candidates to identify preferences that may balance patent law's benefits of incentives against the costs of exclusivity. In Computers and Office Machines, South Korea stands out as the country closest to demonstrating a balance between high-intensity research product imports and exports, ${ }^{153}$ while in Scientific Instruments, the United States is by far the most balanced country. ${ }^{154}$ Each country's intellectual property preferences, in these particular fields, could present a reasonable place to start in trying to understand how to balance the benefits and costs of intellectual property protection in these sectors. ${ }^{155}$ Finally, in the Pharmacy sector, Germany, Spain, and the United States display relatively close correspondence between high-intensity research product imports and exports, indicating that their preferences would align with intellectual property law that best supports the greatest incentives to innovate. ${ }^{156}$

Of course, intellectual property law could be parsed even further. The Comtrade database Electronics and Telecommunications sector, for example, includes semiconductors, electronic integrated circuits, video and sound recording devices, and optical fiber cables. ${ }^{157}$ These are different industries, and each may benefit from different intellectual property laws. The Comtrade

countries studied here), Computers and Office Machines (\$342 billion in exports and \$276 billion in imports), and Scientific Instruments (\$253 billion in exports and \$256 billion in imports) were each more than twice as much as any export or import values for any of the other high research intensity sectors. U.N. Comtrade Database, supra note 108. Pharmacy totals were $\$ 41$ billion in exports and $\$ 49$ billion in imports across the 11 countries. Id.

152 See infra Appendix, Table 3.

153 See infra Appendix, Table 4.

154 See infra Appendix, Table 5.

155 Note that simply because a country has incentives for balanced preferences in a given industry does not mean that the country has optimal patent law for that industry. As discussed, domestic patent law is not industry specific, precluding countries from optimizing incentives to innovate even in industries where they may have strong incentives to do so. See supra pp. 769-70.

156 See infra Appendix, Table 6.

${ }^{157}$ Eurostat, High-Tech PRODUCTS (2014), http://epp.eurostat.ec.europa.eu/cache/ ITY_SDDS/Annexes/htec_esms_an4.pdf. 
database would permit such differentiation. For example, in semiconductors, South Korea happens to display a very close match between the value of semiconductors that it imports $(\$ 4.49$ billion $)$ versus the value of semiconductors that it exports ( $\$ 4.86$ billion). ${ }^{158}$ South Korea would therefore have self-interested incentives in the semiconductor industry to seek a level of patent protection that would optimize overall incentives to innovate in the industry. As noted above, this initial analysis is admittedly relatively rough, designed primarily to show how proxy analysis can work, not to provide definitive conclusions in any area of law.

One of the primary critiques of industry-specific patent law is a concern that it would create an increased opportunity for industry rent-seeking by enabling industries to lobby for industry-favorable patent laws at the expense of consumers. ${ }^{159}$ In the current one-size-fits-all intellectual property context, powerful industries line up on both sides of patent debates, curtailing their ability to rent-seek at the expense of diffuse consumer interests. ${ }^{160}$ Were patent to vary by industry, however, without any objective basis for differentiation, there is a significant fear that there would no longer be cross-industry checks on problematic laws, leading to separate producer-biased law in every industry. ${ }^{161}$ Proxy signal analysis provides a way beyond this industry-specific patent law concern by presenting objective means to identify the appropriate level of propertization within each industry. Proxy analysis thus presents a technique to effectively differentiate private patent law preferences that arise from a desire for greater rent-seeking (which society wants to avoid) from those that are based on a desire to actually increase incentives to innovate (which society should want to foster globally).

\section{CONCLUSION}

The country-based proxy approach introduced here is based on a more holistic and internationally communitarian approach to intellectual property rights and innovation than is common in the existing international political economy. Most current advocacy and policy analysis of international intellectual property debates concerns zero-sum negotiations, pitting technologically advanced countries against the BRICs and other technologically developing countries over the strength of intellectual property rights, trade relations, and foreign investment. Few parties attend to what should be the central issue in intellectual property law: how to optimize net incentives to innovate.

158 U.N. Comtrade Database, supra note 99.

${ }^{159}$ Long, supra note 136, at 48-49; R. Polk Wagner, Of Patents and Path Dependency: A Comment on Burk and Lemley, 18 BERKELEY TECH. L.J. 1341, 1356 (2003).

${ }^{160}$ Jay P. Kesan \& Andres A. Gallo, The Political Economy of the Patent System, 87 N.C. L. REV. 1341, 1347-57 (2009); Long, supra note 54, at 626.

${ }^{161}$ Long, supra note 136, at 49; Wagner, supra note 159, at 1356. 
This vacuity is ironic in the international arena. Treaties can only be achieved if they are perceived as producing benefits by all parties. Such benefits cannot be produced simply by shifting profit flows from one country to another, but they can be created by real efficiency gains in the form of intellectual property laws that increase aggregate incentives to innovate at the global level. ${ }^{162}$ Despite the well-recognized import of optimizing incentives to innovate at the domestic level, this goal has been largely ignored internationally. One reason for the lack of attention has been the apparent indeterminacy of understanding how to improve net incentives to innovate. While the United States, European Union countries, Japan, and others argue that strengthening rights will achieve greater incentives, many developing countries argue they will not, and neither side has reliable empirical evidence with which to support its case. Proxy signal analysis offers a novel means out of such loggerheads to advance the elusive goal of optimally promoting incentives to innovate globally, an objective that could benefit all.

${ }^{162}$ Scotchmer, supra note 12 , at $421-22$. 


\section{APPENDIX}

High Research Intensity Imports and Exports for Selected Industries (2012).

Data is from the United Nations Comtrade Database, available at http://comtrade.un.org/db/mr/rfGlossaryList.aspx\# (last visited Feb. 15, 2014), archived at http://perma.cc/WAX8-A9BC. Figures are in millions of U.S. dollars.

Table 3: Electronics / Telecommunications

\begin{tabular}{|l|c|c|c|c|}
\hline & $\begin{array}{c}\text { High } \\
\text { Research } \\
\text { Intensity } \\
\text { Exports }\end{array}$ & $\begin{array}{c}\text { High } \\
\text { Research } \\
\text { Intensity }\end{array}$ & $\begin{array}{c}\text { High } \\
\text { Research } \\
\text { Intensity } \\
\text { Trade } \\
\text { Differential }\end{array}$ & $\begin{array}{c}\text { Differential / } \\
\text { (Exports + } \\
\text { Imports) }\end{array}$ \\
\hline Brazil & 115 & 14,406 & $-14,290$ & -0.9841 \\
\hline China & 308,821 & 368,209 & $-59,388$ & -0.0877 \\
\hline Germany & 51,961 & 57,550 & $-5,589$ & -0.0510 \\
\hline India & 4,998 & 16,629 & $-11,630$ & -0.5378 \\
\hline Indonesia & 3,670 & 9,823 & $-6,153$ & -0.4560 \\
\hline Japan & 69,910 & 61,790 & 8,120 & 0.0617 \\
\hline Malaysia & 43,677 & 38,513 & 5,164 & 0.0628 \\
\hline Mexico & 22,762 & 71,581 & $-48,820$ & -0.5175 \\
\hline South Africa & 555 & 4,874 & $-4,318$ & -0.7955 \\
\hline South Korea & 83,045 & 45,097 & 37,948 & 0.2961 \\
\hline Spain & 2,599 & 8,741 & $-6,142$ & -0.5416 \\
\hline Ukraine & 452 & 2,422 & $-1,971$ & -0.6858 \\
\hline USA & 132,277 & 158,857 & $-26,580$ & -0.0913 \\
\hline
\end{tabular}

Includes: semiconductors, electronic circuits, video and sound devices, and optical fiber cables 
Table 4: Computers / Office Machines

\begin{tabular}{|l|c|c|c|c|}
\hline & $\begin{array}{c}\text { High } \\
\text { Research } \\
\text { Intensity } \\
\text { Exports }\end{array}$ & $\begin{array}{c}\text { High } \\
\text { Research } \\
\text { Intensity } \\
\text { Imports }\end{array}$ & $\begin{array}{c}\text { High } \\
\text { Research } \\
\text { Intensity } \\
\text { Trade } \\
\text { Differential }\end{array}$ & $\begin{array}{c}\text { Differential / } \\
\text { (Exports + } \\
\text { Imports) }\end{array}$ \\
\hline Brazil & 72 & 4,725 & $-4,653$ & -0.9701 \\
\hline China & 210,321 & 74,087 & 136,234 & 0.4790 \\
\hline Germany & 15,704 & 26,113 & $-10,409$ & -0.2489 \\
\hline India & 448 & 6,207 & $-5,758$ & -0.8652 \\
\hline Indonesia & 2,086 & 2,842 & -757 & -0.1535 \\
\hline Japan & 5,517 & 23,214 & $-17,697$ & -0.6160 \\
\hline Malaysia & 12,797 & 6,409 & 6,388 & 0.3326 \\
\hline Mexico & 19,429 & 14,842 & 4,587 & 0.1339 \\
\hline South Africa & 243 & 2,500 & $-2,257$ & -0.8227 \\
\hline South Korea & 9,241 & 7,912 & 1,329 & 0.0775 \\
\hline Spain & 746 & 4,179 & $-3,433$ & -0.6969 \\
\hline Ukraine & 36 & 314 & -278 & -0.7944 \\
\hline USA & 65,655 & 107,296 & $-41,641$ & -0.2408 \\
\hline
\end{tabular}

Includes: automatic data processing units, storage units, input and output units, and analogue or hybrid data-processing machines 
Table 5: Scientific Instruments

\begin{tabular}{|l|c|c|c|c|}
\hline & $\begin{array}{c}\text { High } \\
\text { Research } \\
\text { Intensity } \\
\text { Exports }\end{array}$ & $\begin{array}{c}\text { High } \\
\text { Intensity } \\
\text { Imports }\end{array}$ & $\begin{array}{c}\text { High } \\
\text { Research } \\
\text { Intensity } \\
\text { Trade } \\
\text { Differential }\end{array}$ & $\begin{array}{c}\text { Differential / } \\
\text { (Exports + } \\
\text { Imports) }\end{array}$ \\
\hline Brazil & 597 & 4,958 & $-4,362$ & -0.7852 \\
\hline China & 59,048 & 113,310 & $-54,262$ & -0.3148 \\
\hline Germany & 47,358 & 23,011 & 24,347 & 0.3460 \\
\hline India & 1,352 & 5,395 & $-4,042$ & -0.5991 \\
\hline Indonesia & 400 & 6,596 & $-6,195$ & -0.8855 \\
\hline Japan & 37,936 & 17,111 & 20,825 & 0.3783 \\
\hline Malaysia & 6,029 & 4,250 & 1,779 & 0.1731 \\
\hline Mexico & 5,451 & 8,885 & $-3,434$ & -0.2395 \\
\hline South Africa & 419 & 1,494 & $-1,075$ & -0.5619 \\
\hline South Korea & 36,075 & 16,648 & 19,426 & 0.3685 \\
\hline Spain & 1,685 & 3,664 & $-1,979$ & -0.3700 \\
\hline Ukraine & 243 & 813 & -570 & -0.5396 \\
\hline USA & 58,744 & 54,379 & 4,365 & 0.0386 \\
\hline
\end{tabular}

Includes: electro-diagnostic apparatuses, optical instruments and apparatuses, measuring instruments and apparatuses, photographic and cinematographic cameras 
Table 6: Pharmacy

\begin{tabular}{|l|c|c|c|c|}
\hline & $\begin{array}{c}\text { High } \\
\text { Research } \\
\text { Intensity } \\
\text { Exports }\end{array}$ & $\begin{array}{c}\text { High } \\
\text { Research } \\
\text { Intensity } \\
\text { Imports }\end{array}$ & $\begin{array}{c}\text { High } \\
\text { Research } \\
\text { Tradensity } \\
\text { Differential }\end{array}$ & $\begin{array}{c}\text { Differential / } \\
\text { (Exports + } \\
\text { Imports) }\end{array}$ \\
\hline Brazil & 2,101 & 2,797 & -697 & -0.1422 \\
\hline China & 3,753 & 2,794 & 959 & 0.1465 \\
\hline Germany & 17,580 & 18,415 & -835 & -0.0232 \\
\hline India & 929 & 1,153 & -224 & -0.1074 \\
\hline Indonesia & 94 & 294 & -200 & -0.5166 \\
\hline Japan & 1,026 & 6,105 & $-5,079$ & -0.7122 \\
\hline Malaysia & 39 & 173 & -134 & -0.6352 \\
\hline Mexico & 314 & 1,511 & $-1,197$ & -0.6558 \\
\hline South Africa & 21 & 367 & -346 & -0.8914 \\
\hline South Korea & 600 & 1,267 & -667 & -0.3574 \\
\hline Spain & 2,806 & 2,990 & -184 & -0.0317 \\
\hline Ukraine & 23 & 375 & -352 & -0.8842 \\
\hline USA & 14,687 & 13,826 & 862 & 0.0302 \\
\hline
\end{tabular}

Includes: antibiotics, vaccines, and hormones 